\title{
Progress on Modified Calcium Oxide Derived Waste-Shell Catalysts for Biodiesel Production
}

\author{
Hui Khim Ooi ${ }^{1}$, Xin Ning Koh ${ }^{1}$, Hwai Chyuan Ong ${ }^{2, *}$, Hwei Voon Lee ${ }^{3}$, Mohd Sufri Mastuli ${ }^{4,5}$, \\ Yun Hin Taufiq-Yap ${ }^{6,7}$, Fahad A. Alharthi ${ }^{8}$, Abdulaziz Ali Alghamdi ${ }^{8}\left(\mathbb{1}\right.$ and Nurul Asikin Mijan ${ }^{1, *}$ \\ 1 Chemical Sciences, Faculty of Science and Technology, Universiti Kebangsaan Malaysia (UKM), \\ Bangi 43600, Selangor, Malaysia; A170358@siswa.ukm.edu.my (H.K.O.); \\ A170752@siswa.ukm.edu.my (X.N.K.) \\ 2 School of Information, Systems and Modelling, Faculty of Engineering and Information Technology, \\ University of Technology, Sydney, NSW 2007, Australia \\ 3 Nanotechnology and Catalysis Research Centre (NanoCat), Institute of Advanced Studies, Universiti Malaya, \\ Kuala Lumpur 50603, Selangor, Malaysia; leehweivoon@um.edu.my \\ 4 School of Chemistry and Environment, Faculty of Applied Sciences, Universiti Teknologi MARA, \\ Shah Alam 40450, Selangor, Malaysia; mohdsufri@uitm.edu.my \\ 5 Centre for Functional Materials and Nanotechnology, Institute of Science, Universiti Teknologi MARA, \\ Shah Alam 40450, Selangor, Malaysia \\ 6 Faculty of Science and Natural Resources, Universiti Malaysia Sabah, Kota Kinabalu 88400, Sabah, Malaysia; \\ taufiq@upm.edu.my \\ 7 Catalysis Science and Technology Research Centre (PutraCat), Faculty of Science, Universiti Putra Malaysia, \\ UPM Serdang 43400, Selangor, Malaysia \\ 8 Chemistry Department Science College, King Saud University, P.O. Box 2455, Riyadh 11451, Saudi Arabia; \\ fharthi@ksu.edu.sa (F.A.A.); aalghamdia@ksu.edu.sa (A.A.A.) \\ check for \\ updates \\ * Correspondence: HwaiChyuan.Ong@uts.edu.au (H.C.O.); nurul.asikin@ukm.edu.my (N.A.M.)
}

Citation: Ooi, H.K.; Koh, X.N.; Ong, H.C.; Lee, H.V.; Mastuli, M.S.; Taufiq-Yap, Y.H.; Alharthi, F.A.; Alghamdi, A.A.; Asikin Mijan, N. Progress on Modified Calcium Oxide Derived Waste-Shell Catalysts for Biodiesel Production. Catalysts 2021, 11, 194. https://doi.org/10.3390/ catal11020194

Academic Editor: Diego Luna

Received: 2 January 2021

Accepted: 26 January 2021

Published: 2 February 2021

Publisher's Note: MDPI stays neutral with regard to jurisdictional claims in published maps and institutional affiliations.

Copyright: (c) 2021 by the authors. Licensee MDPI, Basel, Switzerland. This article is an open access article distributed under the terms and conditions of the Creative Commons Attribution (CC BY) license (https:// creativecommons.org/licenses/by/ $4.0 /)$.

\begin{abstract}
The dwindling of global petroleum deposits and worsening environmental issues have triggered researchers to find an alternative energy such as biodiesel. Biodiesel can be produced via transesterification of vegetable oil or animal fat with alcohol in the presence of a catalyst. A heterogeneous catalyst at an economical price has been studied widely for biodiesel production. It was noted that various types of natural waste shell are a potential calcium resource for generation of bio-based $\mathrm{CaO}$, with comparable chemical characteristics, that greatly enhance the transesterification activity. However, $\mathrm{CaO}$ catalyzed transesterification is limited in its stability and studies have shown deterioration of catalytic reactivity when the catalyst is reused for several cycles. For this reason, different approaches are reviewed in the present study, which focuses on modification of waste-shell derived $\mathrm{CaO}$ based catalyst with the aim of better transesterification reactivity and high reusability of the catalyst for biodiesel production. The catalyst stability and leaching profile of the modified waste shell derived $\mathrm{CaO}$ is discussed. In addition, a critical discussion of the structure, composition of the waste shell, mechanism of $\mathrm{CaO}$ catalyzed reaction, recent progress in biodiesel reactor systems and challenges in the industrial sector are also included in this review.
\end{abstract}

Keywords: biodiesel; transesterification; waste-shell; heterogenous catalyst; green catalyst; alternative fuel

\section{Introduction}

The drastic depletion of fossil fuels and continuous anthropogenic greenhouse gas emissions have prompted the search for alternative renewable and sustainable fuels with efficiency similar to the conventional fuels being used today [1,2]. In this regard, renewable and sustainable biofuels had been seen as an alternative in order to reduce fossil fuel usage [3,4]. Biofuels are generally referred to as liquid or gaseous fuels that are produced from renewable sources [5], which are typically generated from biological material or living organisms, such as plants, animal by-products, or microorganisms [6]. In the past 
10 years, the biofuel industry has experienced an enormous growth, and the main regions contributing to this development are Europe, Brazil and the United States [7]. Currently, the main application of biofuels is as a liquid transportation fuel [8]. In general, biofuels can be divided into four generations, which depend on the raw materials used. First-generation biofuels are mostly derived from subsistence crops. Second-generation biofuels come from non-food biomass or lignocellulosic crops [9]. This is sustainable, cost-effective, and highly available, which will be advantageous for the biorefinery industry. Noteworthy, the use of lignocellulosic crops lead to a zero net carbon dioxide emission and environmental friendliness [10]. The third generation of biofuels come from algae-sources [11,12]. The best means of utilizing raw materials for second and third generation biofuel production is to avoid the issue of food competition. Besides, there are many advantages in producing biofuels from algae, where the triglyceride-based oil extracted from microalgae is 15 to 300 times higher than that of conventional crops in terms of area $[13,14]$. Production of biofuels from genetically modified algae is considered as the fourth-generation of biofuels [15]. The growing interest in fourth-generation biofuel usage strives to lower environmental impact, especially on land usage for crop plantation [16].

Typically, the liquid-based biofuels that widely apply to transportation purposes are biodiesel and bioethanol $[17,18]$. Bioethanol is produced through starch or sugar fermentation, while biodiesel is obtained via the transesterification reaction of oil crops [9]. Biodiesel is used to replace diesel, while bioethanol is used to substitute for petrol [19]. It is noteworthy that the majority of biofuel usage is from biodiesel (76\%) (Figure 1a), followed by bioethanol ( 20\%). Malaysia is one of the most important palm oil producers in the world. The country is experiencing a robust development in new oil palm plantations and palm oil mills. According to a Malaysian Palm Oil Board (MPOB) report [20], the total biodiesel production projected to 2019 in Malaysia shows an increasing trend (Figure 1b), which suggests that Malaysia has an important role to play in fulfilling the growing global need for palm oil-derived biofuels. Biodiesel is generated by esterification of fatty acids (FAs) or transesterification of triacylglycerol (TAG) with alcohol in the presence of a catalyst. Water is co-generated in the esterification reaction of fatty acid, and glycerol is transesterified from TAG (Figure 1c) [21]. Commonly, biodiesel is used in engines with compression ignition with little or no modification [22]. The characteristics of biodiesel are similar but not the same as petroleum diesel. Biodiesel has a high flash point, thus making it safe to store and handle [23]. Biodiesel can be used directly as engine fuel (B100) or blended with diesel in a certain proportion (B20, B50, etc.) [24,25]. Noteworthy, biodiesel has a higher cetane number compared to bioethanol, efficient for engine ignition, while bioethanol has a high-octane number with anti-knocking properties in engines. Earlier literature has discovered that biodiesel exhibited better engine performance than bioethanol, because bioethanol has higher miscibility to water and organic solvent that will contaminate the automotive lubricant parts with resulting corrosion to the engine [26-28].

Generally, there are differences between the esterification and transesterification process. Esterification occurs when a carboxylic acid reacts with alcohol by adding an acid catalyst and produces water as a by-product. Transesterification is the reaction between the vegetable oil or animal fat and alcohol in the presence of a basic catalyst to form ester and glycerol as a by-product $[29,30]$. 


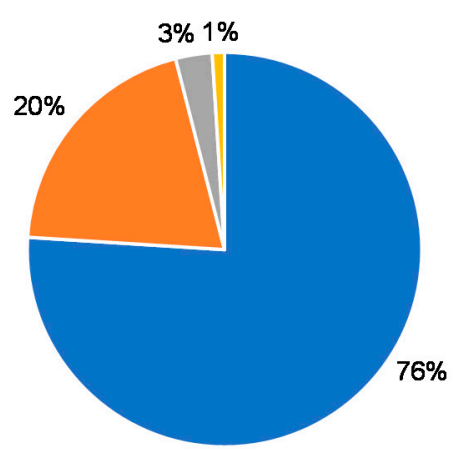

- Biodiesel $\mid$ Bioethanol $=$ Biomethane $=$ Other liquid biofuels

(a)

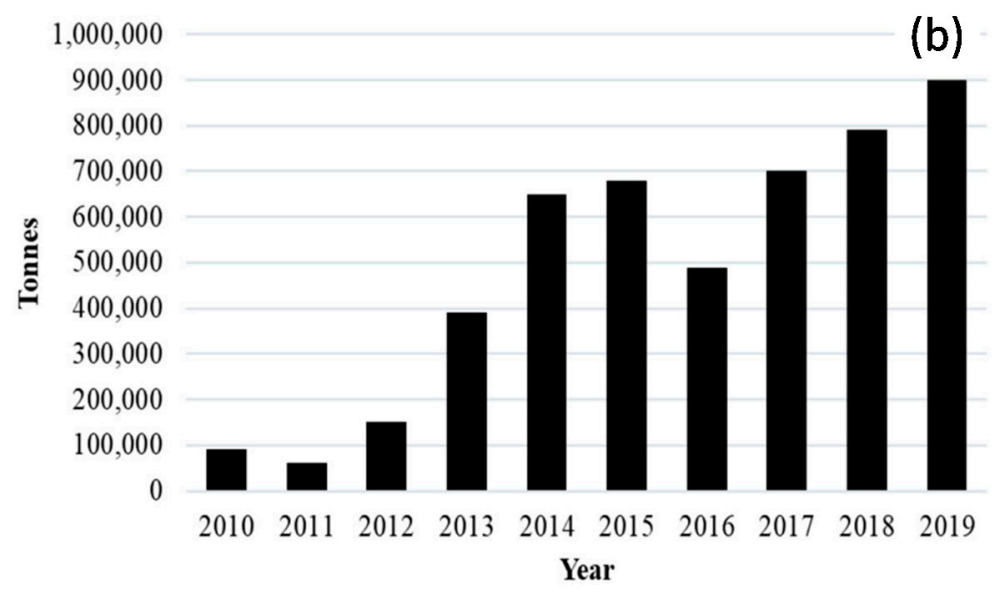

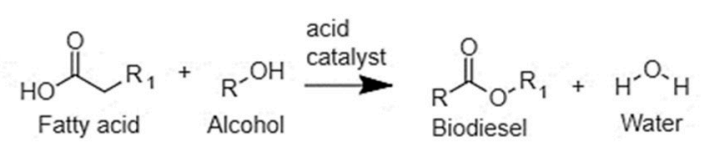

(c)

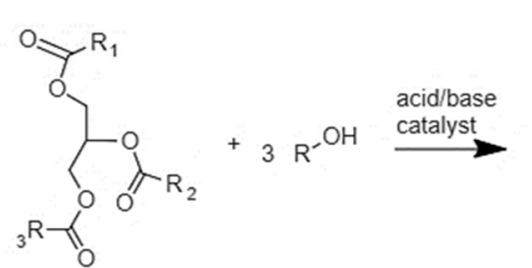

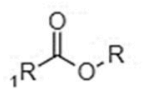

${ }_{2} \mathrm{R}^{\mathrm{O}}{ }^{\mathrm{R}}+\mathrm{HO}^{\mathrm{OH}} \mathrm{OH}$

${ }_{3} \mathrm{R}{ }^{1}{ }^{\circ}, R$

Biodiesel (b) 
directly from natural waste shell/limestone/chemical Ca salt, which reported comparable characteristics to conventional $\mathrm{CaO}$ [41-43]. The high availability of calcium resources makes it a cheap material for various applications.

It was discovered that the waste shells are beneficial for the production of a wide range of value-added chemicals and products, such as 1,2,3-triazoles [44], cyclopentanone [45], 7,8-dihydro-4H-chromen-5(6H)-one [46], dimethyl carbonate [47], steam gasification [48], wastewater treatment [49], soil improvement [50], Portland cement replacement [51] and artificial stone [52]. Xiong et al. [44] studied the synthesis of 1,2,3-triazoles catalyzed by waste oyster shell powders (OSPs)-supported CuBr catalyst (OSPs-CuBr). The copper(I) content of the OSPs-CuBr catalyst was found to have the ability to be reused consistently for eight runs. The authors reported that the prepared OSPs-CuBr catalysts showed high catalytic activity with cost-effectiveness for the larger-scale synthesis of 1,4-disubstituted 1,2,3-triazoles. Sheng et al. [45] investigated the multiple characteristics of the Scapharca Broughtonii shell, conch shell and oyster shell derived catalyst for cyclopentanone self-aldol condensation. Dimer obtained from the self-aldol condensation pathway of cyclopentanone can be used as a high-density fuel or perfume precursor.

The synthesis of 7,8-dihydro-4H-chromen-5(6H)-one using a one-pot three-component condensation catalysed by eggshell at ambient temperature was reported by Mosaddegh \& Hassankhani [46]. Synthesis of 7,8-dihydro-4H-chromen-5(6H)-one and its derivatives contributed to the potential pharmacological activity and as cognitive enhancers for the treatment of neurodegenerative diseases. Based on the high catalytic activity and reusability, the synthesis was completed in a short time with a high yield. The optimum catalyst loading amount to produce the maximum yield was only $0.1 \mathrm{~g}$ of eggshell powder. The catalyst was able to be reused in five runs without losing its catalytic activity. In addition, the authors found that benzylidene malononitrile intermediate was generated instead of 7,8-dihydro$4 \mathrm{H}$-chromen-5 $(6 \mathrm{H})$-one when condensation occurred without the utilisation of the catalyst.

Gao \& Xu [47] examined the viability of eggshell-derived catalyst for the synthesis of dimethyl carbonate (DMC) from the transesterification between methanol and propylene carbonate (PC). DMC is an important methylation and carbonylation agent, which is substituted for dimethyl sulphate and methyl halide in methylation reactions and for harmful phosgene in polycarbonate and isocyanate synthesis. In "green chemistry" and "sustainable societies", the production and chemical applications of DMC are remarkable for its negligible ecotoxicity, low bioaccumulation and persistency. The maximum value of PC conversion and DMC yield were shown after $1 \mathrm{~h}$ under the optimum reaction conditions of $0.8 \mathrm{wt} . \%$ catalyst amount, with methanol to PC molar ratio $10: 1$ in $25^{\circ} \mathrm{C}$ and $1 \mathrm{~atm}$, which are $80 \%$ and $75 \%$, respectively. The eggshell catalyst was able to be reused at least four times with a minimal deactivation.

Note that waste shell is also widely utilized in the steam gasification process $[53,54]$. Fan et al. [48] studied steam gasification of Indonesian sub-bituminous KPU coal (KPU) using an innovative composite $\mathrm{K}_{2} \mathrm{CO}_{3}$-eggshell catalyst in a fixed bed reactor. In this study, eggshells were calcined at a temperature range of $700-900{ }^{\circ} \mathrm{C}$ under $\mathrm{N}_{2}$ atmosphere. The mixture of pure $\mathrm{K}_{2} \mathrm{CO}_{3}$ and calcined eggshells were impregnated with the KPU. The introduction of $\mathrm{H}_{2} \mathrm{O}$ and $\mathrm{N}_{2}$ gasified the resultant char after completion of the pyrolysis process. The primary product gases were $\mathrm{H}_{2}, \mathrm{CO}, \mathrm{CO}_{2}$ and $\mathrm{CH}_{4}$. The experiment resulted in improved yields of $\mathrm{H}_{2}$ and $\mathrm{CO}$ in the presence of the composite catalyst with a composition of $15 \% \mathrm{~K}_{2} \mathrm{CO}_{3}$ and $5 \%$ eggshell. $\mathrm{H}_{2}$ yield with this composite catalyst was increased by $6 \%$ and $123 \%$, respectively, compared to that obtained by utilizing pure $\mathrm{K}_{2} \mathrm{CO}_{3}$ and no-catalyst. Besides, an increase in carbon conversion rate constant of more than three times in the range of $700-900{ }^{\circ} \mathrm{C}$ was also achieved by this composite catalyst, as it reduces the activation energy of gasification by about $38 \%$ compared to the no-catalyst reaction.

In addition, waste shells can be used for wastewater treatment. Evidently, Luo et al. [49] utilised waste oyster shell in a bio-contact oxidation tank to treat tidal combined river wastewater. Wastewater quality including chemical oxygen demand (COD), five days' biochemical oxygen demand $\left(\mathrm{BOD}_{5}\right)$, salinity and ammonia-nitrogen $\left(\mathrm{NH}_{3}-\mathrm{N}\right)$, total phos- 
phorus (TP) and total suspended solids (TSS) was analysed. According to the average removal percentage of these chemicals $(80.05 \%, 85.02 \%, 86.59 \%, 50.58 \%$ and $85.32 \%$, respectively), it was confirmed the waste oyster shell bio-filler was efficient in pollutant removal. The oyster shell as active filler indirectly improved the recovery ability of the system in the bio-contact oxidation tank by allowing the microbes from the biofilm that decompose pollutants to attach and grow on it. The growth of microbes and the high porosity of oyster shell reduced the sludge amount form in the bio-contact oxidation tank, thereby ensuring accessibility in the one-year experiment.

Soil contamination has impacted on agricultural toxicity, and thereby threatened human and animal health. Noteworthy, agricultural soil improvement was also achieved by mixing the soil with calcined waste oyster shell. This has been successfully implemented by Bi et al. [50]. Moreover, it was discovered that the amount of heavy metal cadmium (Cd) and arsenic (As) in the soil was remarkably reduced. The oyster shells were calcined at various temperatures between $400-800^{\circ} \mathrm{C}$ and it was discovered that higher calcination temperature $\left(800^{\circ} \mathrm{C}\right)$ rendered excellent removal of $\mathrm{Cd}$ and As. It is noteworthy to state that the vegetables grown in this improved soil are within the $C$ and $A$ categories regarding food safety standards.

In the case of the construction sector, waste shell partially replaced expensive Portland cement and it was discovered that it has the ability to reduce $\mathrm{CO}_{2}$ emissions. The mixture of cement, sand, water and eggshell powder for mortar production was investigated by Pliya \& Cree [51]. The strength, compression and flexural of the mortar decreased as the replacement percentage of eggshells increased. Hence, the authors suggest that eggshells could act as a filler to enhance these properties. Waste shells were also utilised in the production of artificial stone with high mechanical properties artificial. Silva et al. [52] created artificial stone by mixing oyster shell powder with unsaturated polyester resin. The authors reported that flexural strength of oyster shell stone (20 $\pm 2 \mathrm{MPa})$ was higher than marble (natural stone) and even than Aglostone (marble powder plus polyester resin). The authors also inferred that the flexural strength of oyster shell stone might be improved to 50MPa by adding glass microcrystals which are higher than Marmoglass ( $>32 \mathrm{MPa}$ ). Its hardness was also tested an $1216 \pm 120 \mathrm{MPa}$ was obtained which is comparable with marble (1471 MPa). This shell stone is currently is available for countertops and worktops, laboratory benches, etc. Based on the above findings, it can be summarized that waste shells are beneficial for a variety of applications. Since the waste shell is a renewable and cheap alternative, its implementation in a variety of applications will not only simultaneously decrease manufacturing cost, but also reduce the burden on the environment and ecological system.

Based on the above applications of waste shell, obviously it is very promising to be used as catalyst for effective production of biodiesel; hence, this paper focused on a detailed review of natural waste shell as catalyst for biodiesel production [55]. To date, many studies have reported that $\mathrm{Ca}^{2+}$ ion from $\mathrm{CaO}$ catalyst was easily leached out during the reaction, and hence the $\mathrm{CaO}$-catalysed reaction is still far from using an ideal catalyst. Indeed, the limitation of $\mathrm{CaO}$ has been solved chemical modification, such as incorporation of $\mathrm{AMO}$, transition metal oxide (TMO) or metal functionalization approaches. Several reviews focused on commercial $\mathrm{CaO}$ and eggshell-derived $\mathrm{CaO}$ for biodiesel production $[56,57]$. In the present study, we aim to discuss the remarkable progress of waste shell-derived $\mathrm{CaO}$ for biodiesel production from 2011-2020, besides a comparative study of transesterification activity summarized for conventional $\mathrm{CaO}$, waste shell-derived $\mathrm{CaO}$ and modified wasteshell-derived $\mathrm{CaO}$ catalysts. The review will highlight the reaction mechanism of both $\mathrm{CaO}$ and modified $\mathrm{CaO}$ derived from waste shells for biodiesel production. Lastly, the review summarizes the existing technology of reactor systems for advance biodiesel production.

\subsection{Solid Base Catalysts}

Solid based catalysts are principally referred to as a heterogeneous system in the reaction medium, where the solid surface consists of active sites that act as a Bronsted base 
(proton acceptor) or Lewis base (electron-pair donor) [58]. There are a few characteristics for a catalyst to be recognised as a solid base catalyst. First, when the surface is characterised, it shows that the basic sites exist. Secondly, the catalyst shows a correlation effect between catalytic activity and the basicity density as well as the distribution strength of basicity. Thirdly, the reaction pathways are similar to the base-catalysed reactions in a homogeneous system. Lastly, the generation of anionic intermediates during the reaction indicates the presence of a base-catalysed pathway [59]. AMOs including $\mathrm{MgO}, \mathrm{CaO}, \mathrm{SrO}$, and $\mathrm{BaO}$, have been intensively studied as heterogeneous basic catalysts for transesterification of triglycerides with methanol [60]. The basic strength increased in the order of $\mathrm{MgO}<\mathrm{CaO}<$ $\mathrm{SrO}<\mathrm{BaO}$, which was attributed to the decrease in electro-negativity of the conjugated metal cation of AMO. Note that the catalytic activities of transesterification exhibited in the same sequence. Among these AMOs, $\mathrm{CaO}$ exhibited promise as a heterogeneous catalyst for biodiesel production [58,61,62]. It is noteworthy to mention that $\mathrm{CaO}$ is less soluble in methanol, stable at high temperature, possesses high reaction activity, is non-toxic, naturally abundant and cheap [63,64]. Faruque et al. (2020) [18] reported that CaO showed high stability and long life span especially for moderate reaction conditions. Similar findings were observed [65-67], where the majority of the $\mathrm{CaO}$ catalysts exhibited greater reusable capability ( $>5$ cycles) without undergoing any regeneration process.

\subsection{Waste Shell-Derived Catalyst}

World aquaculture production is increasing rapidly as seafood demand grows and marine capture production stalls. Commercial mollusk shells (referred to as mollusks or shellfish) are an important food component for the global economy, where the commercialisation of mollusks is in second place at a worldwide level. Annually, about 23\% ( 16.1 million tons) of mollusks are produced, which is equivalent to 19 billion USD [52,57]. According to the FAO global Fishery and Aquaculture statistics database, there are 79 mollusk species listed as cultured and 93 species considered as captured species. They can be classified into four major groups: clams, oysters, mussels and cockles. The clam and oyster are the most prevalent that contribute, 38\% and 33\%, respectively, to global production [68]. Based on the overview of mollusk farming, Asia has been the main producer of mollusks, followed by Europe and the Americas. China is the leading producer for mollusks (83.4\%) followed by Japan (2.2\%), South Korea (1.9\%), Thailand (1.4\%) and Vietnam $(1.2 \%)[57,69]$. In 2016, Asia yielded 158.35 million tonnes out of 171.39 million tonnes for total global production [70]. When considering the mollusks' role as a global food source, one of the most worrying factors is the huge amount of residue generated. Most of the waste shells are deposited in landfills, abandoned on land, or returned to the sea, thus causing incalculable environmental impacts. When the aquaculture wastes are deposited in the soil, it will contaminate the environment and create an unfavorable strong odor [52]. Apart from mollusk shells, eggshells are also widely generated during food processing and manufacturing plants as by-products [71]. Eggs represent the main ingredient in a variety of food products such as cakes, salad dressings and fast foods, whose production results in several daily tons of eggshell waste, and incurs considerable global disposal costs. About 250,000 tons of eggshell waste is produced annually worldwide [72]. Similar to the scenario of mollusk waste shell, improper disposal of waste eggshell will result in environmental odor from biodegradation. Thus, it is strongly suggested that all of the waste shells should be recycled, reused and channeled as a valuable product for different applications. Indeed, utilization of waste shell is a priority for sustainable development achievement. Nowadays, waste shells are reused and refined in various fields, such as water treatments, cosmetics, toiletries, food, agrochemicals, bioenergy and pharmaceuticals [70]. Interestingly, waste shell can be potentially used as a bio-based calcium source of catalyst for biodiesel production. Notably, the use of waste shell in biodiesel production is in line with the purpose of the biodiesel development, which is a greener and environmentally friendly product. 


\subsection{Composition of Waste Shell}

Many invertebrates have produced hard-shells composed of crystallized biogenic minerals to protect and support their soft bodies [73]. The major component in the shells is calcium carbonate (calcite) with a composition of approximately $95-99 \%[54,57,74]$. Other than calcium carbonate, mollusk shells also contain organic matrix proteins as secondary compositions, which are known to be important for the nacreous layer and critical in calcification [73]. Mollusk shells are divided into three main layers which are the periostracum, prismatic and nacreous layers. The periostracum layer is the external layer that is composed mainly of conchiolins. The middle layer is called the prismatic layer, which is mainly made up by oriented calcite crystals. The inner pearlite layer is mainly composed of orientated aragonite crystals [75].

In the case of eggshell, it can be classified as membranous for snakes and lizards; pliable for most turtles; and rigid for certain turtles and geckos and all species of crocodiles, birds and dinosaurs. The eggs of the avian species are the highest grade of amniotic eggs among oviparous vertebrates. Eggshell is a complex bio-ceramic that allows the regulation of metabolic gas and water exchange, and its properties can be finely tuned according to the environmental conditions of a given species. Calcium carbonate (calcite) is the main component in eggshell, and is the major inorganic substance found in an egg that makes up about $98 \%$ of the chemical composition [76]. Other minor components in eggshell are $\mathrm{Mg}(0.9 \%)$ and $\mathrm{P}(0.9 \%)$ [77].

There are four main polymorphs of calcium carbonate, which are calcite $\left(\mathrm{b}-\mathrm{CaCO}_{3}\right)$, vaterite $\left(\mathrm{m}-\mathrm{CaCO}_{3}\right)$, aragonite $\left(1-\mathrm{CaCO}_{3}\right)$ and amorphous calcium carbonate. Calcite, aragonite and vaterite are polymorphs in nature in order of increasing stability and can co-exist in numerous marine organisms [78,79]. Noteworthy, calcite with rhombohedral structures is the most stable polymorph of calcium carbonate followed by orthorhombic Aragonite. It forms elongated structures called columns, palisades or crystallite. The presence of magnesium $(\mathrm{Mg})$ in aragonite creates weaker bonds in the crystal structure; thus, it is more soluble. Vaterite with a hexagonal structure, which is the most unstable polymorph, readily transforms into aragonite or calcite at room temperature. Therefore, only a small amount of vaterite can be found in nature [80-82]. Other than calcium carbonate, some shells are also composed of chitin. For example, the major composition of oyster shells is calcium carbonate with a chitin outer layer, and an inner layer consisting of calcite $(90 \%)$ and aragonite $(10 \%)$ [83]. Chitin is one of the most widely abundant biopolymers in the waste shell, next to cellulose. Chitin is made up of $\alpha$-(1-4)-linked 2-acetamido-2-deoxy-D-glucose with $\beta-(1 \rightarrow 4)$ linkage, known as oligomer. Commercial chitin is mostly extracted from crustacean shells. About $40 \mathrm{wt} . \%$ of waste shells is composed mainly of chitin, lipid, meat offcuts, calcium carbonate and pigments [78]. Depending on the species and cultivation condition of the aquaculture, the composition of chitin in shells will differ from $15-40 \%$. Despite this, the highest composition chitin is tightly bound with calcium (20-50\%) and proteins $(20-40 \%)$ that give a structural stiffness to the shell. Hence, multiple steps of pretreatment are required to recover each component [84].

\section{Recent Trend in Waste Shell-Derived Catalyst for Biodiesel Production}

Valorisation of waste shell rich calcium as natural material for catalyst synthesis is an outstanding topic. It is considered to be environmentally friendly and provides various beneficial impacts on the biodiesel industry. Figure 2a shows that the scientific investigation of biodiesel production in the presence of a catalyst is widely available; here the statistics indicate an increment from 579 publications in 2010 to 950 publications in 2020. The report indicates that within 10 years (2010-2020), China was the country with the highest number of publications in this field, with 1415 out of 8409 publications from around the world, followed by India (1383) and Malaysia (816) (Figure 2b). However, there are only about 205 publications related to waste shell-derived catalyst (Figure 2c). Figure $2 \mathrm{~d}$ reveals the trend of countries with publications related to waste shell-derived catalyst for biodiesel production from 2010 to 2020. It can be seen that India has published 55 studies 
on the subject, which accounts for $3.98 \%$ of total publications. Malaysia comes in second with 39 publications, $4.78 \%$ of the total. Publications from Thailand (23), China (19) and Indonesia (19) are also relatively high in number when compared to other countries.
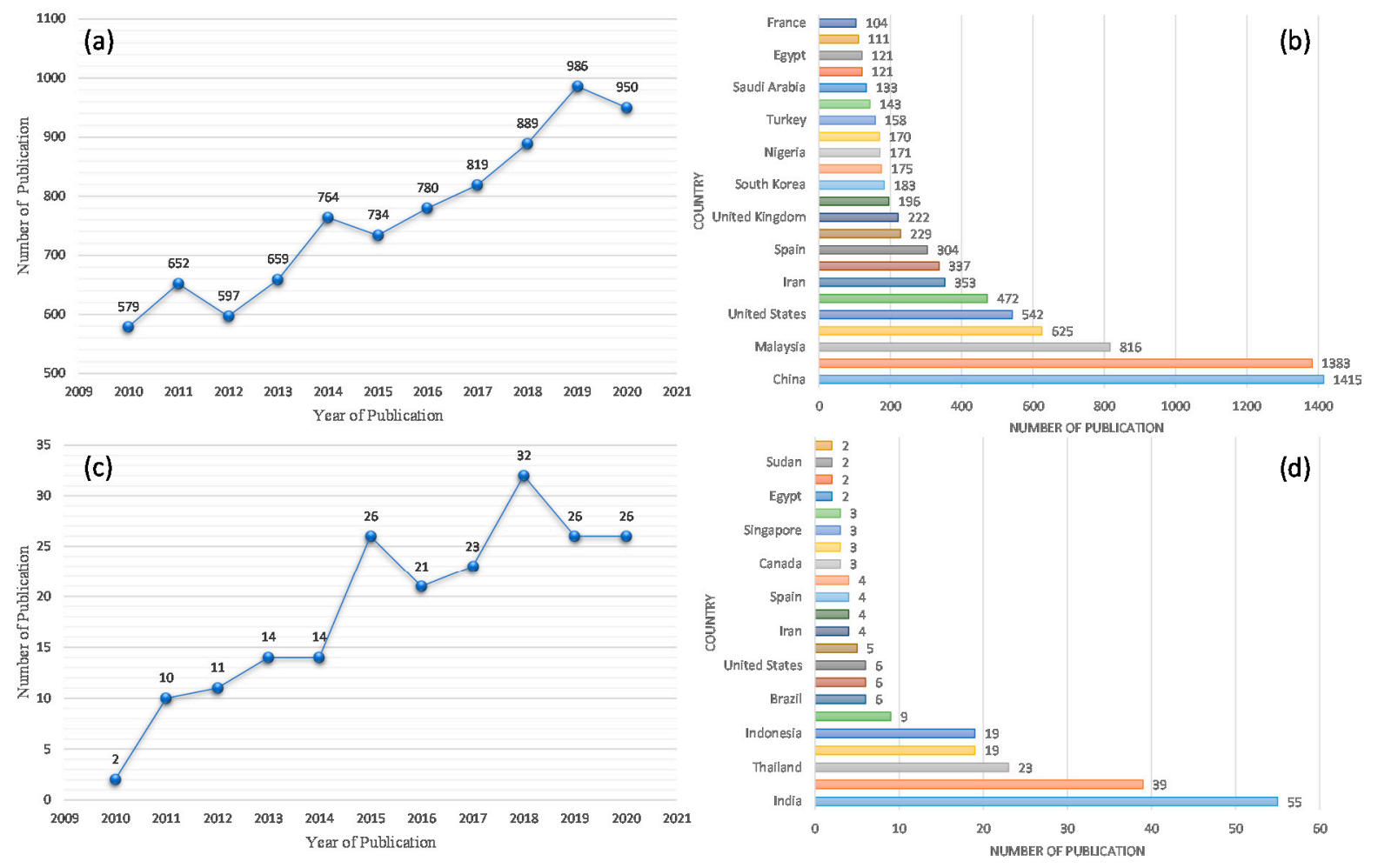

Figure 2. (a) Publication trends on biodiesel production in the presence of catalyst from 2010-2020, (b) Publications on biodiesel production in the presence of a catalyst based on country from 2010-2020, (c) Publication trends on waste shell catalyst in biodiesel production from 2010 to 2020, (d) Publications on waste shell catalyst in biodiesel production based on country from 2010-2020 (data collected from SciFinder Database).

\section{Waste Shells vs. Modified Waste Shells Catalyst}

\subsection{Waste Shells-Derived Catalyst for Biodiesel Production}

Table 1 presents various types of waste shell-derived catalysts for transesterification of vegetable oil. The majority of the waste shells can be transformed into active $\mathrm{CaO}$ after calcination at a temperature within the range of $800-1000{ }^{\circ} \mathrm{C}$. It can be seen that the majority of the pure $\mathrm{CaO}$ derived from waste shells successfully converted the low FFA feedstock (palm oil, Camelina Sativa oil, soybean oil and some low FFA waste cooking oil) into biodiesel [74,85-92]. High biodiesel yield (90-97\%) was achieved by HangunBalkir [74] from transesterification of Camelina sativa oil (FFA: 1.6\%) over waste eggshell and lobster shell-derived catalysts. Both waste shells were prepared by calcination at $900{ }^{\circ} \mathrm{C}$. The transesterification was catalysed by $1 \%(w / w)$ catalyst loading with $12: 1 \mathrm{MeOH}$ :oil molar ratio at $65^{\circ} \mathrm{C}$ for $3 \mathrm{~h}$. The authors compared the biodiesel yield that was catalysed by commercial $\mathrm{CaO}$, waste eggshell and lobster shell. The maximum biodiesel produced was $99 \%, 97 \%$ and $90 \%$, respectively. Buasri et al. (2013) [86] used waste mussel, cockle and scallop shell as a catalyst for transesterification of palm oil (FFA: $0.1 \%$ ) at $65{ }^{\circ} \mathrm{C}$ with $\mathrm{MeOH}$ :oil molar ratio of 9:1 within $3 \mathrm{~h}$ and $10 \mathrm{wt} . \%$ catalyst loading under $1 \mathrm{~atm}$ pressure in a glass reactor. The waste mussel shell-derived catalyst with a large surface area of $89.91 \mathrm{~m}^{2} / \mathrm{g}$ and pore volume of $0.130 \mathrm{~cm}^{3} / \mathrm{g}$ produced $97.23 \%$ of biodiesel. However, scallop $\left(74.96 \mathrm{~m}^{2} / \mathrm{g}, 0.097 \mathrm{~cm}^{3} / \mathrm{g}\right)$ and cockle $\left(59.87 \mathrm{~m}^{2} / \mathrm{g}, 0.087 \mathrm{~cm}^{3} / \mathrm{g}\right)$ shell-derived catalysts produced $96.68 \%$ and $94.47 \%$, respectively. Reusability is the most important feature of heterogeneous catalysts in industrial applications. Based on former literature, 
the majority of waste shell-derived $\mathrm{CaO}$ catalysts can be reused up to five times without further undergoing regeneration treatment $[74,88,93,94]$. Notably, Laskar et al. successfully regenerated the $\mathrm{CaO}$ derived from snail shell [92]. After being washed with water and dried, the spent catalyst was reactivated at $900^{\circ} \mathrm{C}$ for $4 \mathrm{~h}$. The experimental results showed that $91 \%$ of biodiesel yields were obtained consistently within the eighth run but dropped to $77 \%$ sharply in the ninth cycle over the regenerated catalyst, suggesting that the active sites of pure $\mathrm{CaO}$ catalyst could be recovered after undergoing the regeneration process. It is worth mentioning that, based on Table 1, the majority of pure $\mathrm{CaO}$ derived from shell still exhibited lower catalyst stability.

When comparing the conventional reflux system with microwave-assisted transesterification, it was observed that the use of a microwave system successfully converts the biodiesel within a shorter reaction time [95]. This fact was in agreement with Khemthong et al. [87], whereby an effective transesterification activity on palm oil (FFA: $0.55 \%$ ) using $\mathrm{CaO}$ derived from waste eggshells using the microwave at $900 \mathrm{~W}$ has been achieved within $4 \mathrm{~min}$. This method improved the transesterification rate as compared to the traditional heating method for biodiesel production. Various conditions were tested to obtain the optimum condition in order to carry out transesterification reaction. Overall, the authors produced a maximum biodiesel yield of $96.7 \%$ using $15 \mathrm{wt} \%$ of catalyst loading amount and $\mathrm{MeOH}$ :oil molar ratio of $18: 1$ at $122{ }^{\circ} \mathrm{C}$. The effectiveness of microwave technology is due to the presence of electromagnetic radiation that transmits energy directly to the molecule of reactants, thus resulting in intense local heating able to accelerate molecular restructuring. Some studies $[87,90,93]$ reported on microwave-assisted biodiesel production and noted that high microwave power could accelerate the reaction and improve product yield in a short time (4-5 $\mathrm{min})$.

Waste cooking oil (WCO) refers mainly to frying oil used at high temperatures, edible fat mixed in kitchen waste and oily wastewater [96] and has been shown to have a high content of acidic compounds (FFA: $>3 \%$ ) [97]. The amount of FFA from feedstock is an important criterion for catalyst selection. WCO with high FFA concentration will result in increased soap formation with an alkaline catalyst, so it needs to be pretreated with an acid catalyst to reduce FFA concentration [98]. Due to this reason, it can be suggested that the WCO with low FFA value will easily trans-esterify to biodiesel. Evidently, Aitlaalim et al. [88], Lin et al. [90] and Sirisomboonchai et al. [91] successfully transesterified the WCO with FFA value within the range of $0.30-0.61 \%$. It was found that the biodiesel yield was within the range of $86-94 \%$. Since the FFA for these WCO is lower than $3 \%$, an undesired saponification reaction would not occur during the transesterification reaction.

Although waste shell-derived $\mathrm{CaO}$ are effective catalysts for transesterification of low FFA feedstock with high biodiesel yield (90-99\%) and high reusability (3-6 cycles), waste shell-derived $\mathrm{CaO}$ shows poor performance in the presence of feedstock with high FFA and moisture. The presence of moisture favors hydrolysis of triglyceride to diglycerides and more FFAs, while the presence of FFA with high acidity favors the reaction with the basic $\mathrm{CaO}$ catalyst. Generally, $\mathrm{CaO}$-catalyzed transesterification process renders two plausible pathways; the first preferable step is a partial heterogeneous reaction attributed to basic sites of the Ca-O surface; while the second unfavorable step is a homogeneous reaction that contributes to the $\mathrm{Ca}^{2+}$ liquid species that leach into methanol, which causes the loss of active sites. The leached $\mathrm{Ca}^{2+}$ further reacts with FFA in oil via a saponification process that forms soap as by-product. The formation of soap during reactions resulted in the poisoning of the catalyst surface, which resulted in the reduction of both transesterification reactivity and reusability. Besides, the presence of catalyst-soap suspension in the reaction medium makes the separation between glycerol and biodiesel product difficult and thus reduces the biodiesel yield [99].

Therefore, further modification of $\mathrm{CaO}$ derived from the waste shell is needed as this may enhance the hydrophobicity of the catalyst as well as the generation of new acid sites (Lewis or Bronsted acid sites) in CaO system. The presence of both acid-based properties of the catalyst are crucial for the process of biodiesel production, especially highly adapted to a 
wide-range of low-cost and high acid oil feedstock. It was noted that Lewis/Bronsted bases sites (attributed to lattice oxide \& $\mathrm{OH}^{-}$phases) favor transesterification of triglyceride oil to ester, while Lewis/Bronsted acid sites (attributed from metal and $\mathrm{H}^{+}$phases) favor the esterification process of FFA in oil into ester. Thus, the presence of acid sites from modified $\mathrm{CaO}$ appeared to be insensitive to FFAs and moisture and hindered the saponification reaction, which increased yield [100]. Generally, the basic nature and acid active sites of catalysts can be determined by several types of analysis, such as Hammett's indicators (references), and $\mathrm{CO}_{2} / \mathrm{NH}_{3}$ desorption from thermal programmed desorption (TPD), or a microcalorimetry instrument that provides the basic/acid density as well as the different strength (weak, medium, and strong) of the adsorption profile. On the other hand, indepth information of Lewis and Bronsted sites for acid-based profile, usage of model catalytic reactions, and theoretical/modeling approaches to determine acid-base actives site can obtained from other techniques such as Fourier-transform infrared spectroscopy (FTIR), Electron Spin Resonance Spectroscopy (ESR), Nuclear magnetic resonance (NMR), photoluminescence, Raman, UV-Visible Spectroscopy (UV-Vis), and X-Ray Photoelectron Spectroscopy (XPS) [101].

\subsection{Modified Waste Shells-Derived Catalyst for Biodiesel Production}

As mentioned above, waste shells are natural and renewable resources that can be used for the preparation of $\mathrm{CaO}$-based catalyst. Calcium carbonate in the waste shells can be decomposed to $\mathrm{CaO}$ through calcination, which can be used as bio-based material for biodiesel production [74]. Although $\mathrm{CaO}$ is highly active for the transesterification process, the $\mathrm{CaO}$ is limited in stability and sensitive to FFA content and frequent dissolution and leaching of $\mathrm{Ca}^{2+}$ ions. This phenomenon resulted in reduction of catalytic activity during a reusability study, where the leached $\mathrm{Ca}^{2+}$ contaminated the biodiesel product at the end of the process $[61,102]$. Indeed, $\mathrm{CaO}$ catalysts have been extensively modified by adding a second or more chemical components to improve its catalytic activity and the stability of the system. Generally, these modified $\mathrm{CaO}$ catalysts were prepared via incorporation of $\mathrm{AMO}, \mathrm{TMO}$, mesoporous material, and through functionalization approaches.

Based on the previous section, other $\mathrm{AMO}$ including $\mathrm{MgO}, \mathrm{SrO}$, and $\mathrm{BaO}$ have been intensively studied as heterogeneous basic catalysts for transesterification of triglycerides [60]. Taking into account the superior basicity characteristic for these AMOs [103-105], combining these with $\mathrm{CaO}$ derived from waste shell has been focused on. Boro et al. [104] investigated biodiesel production from WCO by using a series concentration of $\mathrm{Ba}(0.5 \%$, $1.0 \% 1.5 \%$ ) doped waste Turbonilla striatula shell-derived $\mathrm{CaO}$ catalyst. It was found that, as the $\mathrm{Ba}$ concentration increased from $0.5 \%$ to $1.0 \%$, the basicity properties increased, and reduced when the Ba concentration increased to $1.5 \%$. This author suggested that reduction of basicity is due to reduction in the $\mathrm{CaO}$ species. The study revealed that Ba1.0/ CaO showed higher biodiesel yield (98\%) and the capability to be reused four times. Similarly, Boro's study in transforming Nahor oil (FFA: 8\%) [106] and WCO (FFA: $11 \%$ ) [104] into biodiesel rich fuel over Ba modified waste shell-derived $\mathrm{CaO}$ catalyst and $\mathrm{Ba} / \mathrm{CaO}$ catalysts, yielded biodiesel of $98 \% . \mathrm{Mg} / \mathrm{CaO}$ synthesized from waste eggshell was also found effective in transesterification of edible waste oil. EDX analyses showed $\mathrm{MgO} / \mathrm{CaO}$ catalyst consisting of $26.03 \%$ calcium, $41.93 \%$ oxygen, and $32.04 \%$ magnesium. The highest biodiesel yield of $98.37 \%$ was produced at the optimum condition of $4.5 \mathrm{wt} \%$ catalyst loading amount, 16.7:1 MeOH:oil molar ratio at $69{ }^{\circ} \mathrm{C}$ for $7 \mathrm{~h}$ with reusability up to six times [105]. Tomano et al. [103] investigated the properties of Sr substituted cuttlebone-derived $\mathrm{CaO}$ for the conversion of biodiesel from palm olein. The Sr species were loaded within a range of 1-10 wt.\%. Different content of Sr dispersion on CaO surface was indicated by the mapping analysis. However, the rich $\mathrm{Sr}$ species on the $\mathrm{CaO}$ surface could result in a reduction of BET surface area of the $\mathrm{Sr} / \mathrm{CaO}$ catalyst. Overall, $\mathrm{Sr} / \mathrm{CaO}$ with 1 wt.\% of $\mathrm{Sr}$ loading has the highest BET surface area. The transesterification was carried out in $60{ }^{\circ} \mathrm{C}$ with 9:1 methanol/oil ratio and $5 \mathrm{wt} . \%$ catalyst loading for $3 \mathrm{~h}$. The $1 \mathrm{wt} . \% \mathrm{Sr} / \mathrm{CaO}$ rendered highest conversion of biodiesel at $95 \%$. Not that the biodiesel 
yield produced by $\mathrm{AMO}$ doped $\mathrm{CaO}$ was mostly $>95 \%$ and the catalyst can be reused up to $>5$ times after regeneration treatment.

Transition Metals (TM) such as $\mathrm{Zn}, \mathrm{Fe}, \mathrm{Mn}, \mathrm{Al}, \mathrm{Mo}, \mathrm{Cu}$, etc., are important materials that have been used in many catalytic reactions. Indeed, TMOs are commonly used in the process of oxidation, dehydrogenation, selective oxidation/reduction, ammoxidation, metathesis, water-gas shift, etc. The unique physicochemical properties of TMOs favour the selective reaction pathways such as surface acidity and basicity, cationic and anionic vacancies, high mobility of lattice oxygen, etc. [107]. Due to the excellent chemical properties of TMOs, the chemical properties of $\mathrm{CaO}$ could be tailored through TMO addition. Hence, TMO modified $\mathrm{CaO}$ will have both acidic-basic sites, which actively convert high FFA feedstock to biodiesel via both esterification and transesterification processes [108]. Evidently, Joshi et al. [109] successfully converted high FFA feedstocks (Jatropha (6.25\%) and Karanja oils (8.75\%)) over $\mathrm{Zn}, \mathrm{Fe}$, Mn and Al-doped $\mathrm{CaO}$ derived from eggshell to biodiesel. Interestingly, the specific surface area and basicity character of TMO doped $\mathrm{CaO}$ catalyst are greater than for pure $\mathrm{CaO}$. The high basicity character of TMO modified $\mathrm{CaO}$ is possibly due to the existence of synergistic interaction between the multi-metal ions. The authors also stated that the electron-donating property of oxygen anion in the TMO makes the combined metal ions more electropositive, which may lead to the formation of more Lewis base sites on the surface of $\mathrm{CaO}$. As expected, the TMO doped $\mathrm{CaO}$ effectively transesterified and esterified the high FFA feedstocks with yield within a range of 76-98\% and have the ability to be reused for four cycles with a biodiesel yield within the range 92-95\%. Similarly, Rahman et al. reported on the transesterification of eucalyptus oil by using $\mathrm{Cu}$ and $\mathrm{Zn}$ doped $\mathrm{CaO}$ derived from eggshell [110]. $\mathrm{Zn}$ doped $\mathrm{CaO}$ exhibited excellent basic sites, a larger surface area and pore volume than $\mathrm{Cu}$ doped $\mathrm{CaO}$ and $\mathrm{CaO}$ itself. The transesterification of eucalyptus oil was performed at the optimum condition: $5 \mathrm{wt} . \%$ catalyst loading, $6: 1 \mathrm{MeOH}$ :oil molar ratio, $65{ }^{\circ} \mathrm{C}$ for $2.5 \mathrm{~h}$. The biodiesel yield for catalyzed transesterification of eucalyptus oil was in the sequence of $\mathrm{Zn} / \mathrm{CaO}>\mathrm{Cu} / \mathrm{CaO}>$ $\mathrm{CaO}$. The authors reported the reusability of the $\mathrm{Zn} / \mathrm{CaO}$ up to seven times with the yield of the biodiesel maintained $>85 \%$ to the sixth run. The effectiveness of TMO modified $\mathrm{CaO}$ was agreed by Kaur and Ali's study, in which the transesterification of jatropha oil occurred over Mo doped $\mathrm{CaO}$ at reaction parameter: 12:1 ethanol to oil molar ratio, $65^{\circ} \mathrm{C}$ using $5 \mathrm{wt} . \%$ of catalyst loading within $4.5 \mathrm{~h}$ of reaction time. The results showed that $99 \%$ of biodiesel was achieved and the catalyst can be reused up to five times [111]. Das et al. [112] utilised cobalt-doped waste eggshell derived $\mathrm{CaO}$ catalyst, in the conversion of lipid extracted from Scenedesmus quadricauda species algae to biodiesel. In this work, about $98 \%$ of algae oil was successfully converted into biodiesel over $\mathrm{Co} / \mathrm{CaO}$ catalyst. Note, the $\mathrm{Co} / \mathrm{CaO}$ exhibited stable activity for at least three reaction runs. The authors remarked that partial leaching of the Co and deposition of reaction products to the catalyst active sites were the possible reasons for lower catalyst stability. More recent studies for biodiesel production using TMO doped $\mathrm{CaO}$ derived from waste shell $(\mathrm{W}-\mathrm{Mo} / \mathrm{CaO}$, $\mathrm{Zn} / \mathrm{CaO}$ and $\mathrm{Fe}_{3} \mathrm{O}_{4} / \mathrm{CaO}$ ) have been reported by Mansir et al. [113], Borah et al. [114] and Helwani et al. [115]. In general, the TMO doped catalyst produced high biodiesel yield within the range $90-97 \%$ and reported that these catalysts can be reused in up to five consecutive runs. The above findings suggest that TMO modified $\mathrm{CaO}$ catalyst has been found to be the most promising technique in overcoming the dissolution of active $\mathrm{Ca}^{2+}$ and improving the catalyst stability.

Functionalization is a treatment incorporating other chemical elements or compounds such as alkaline $(\mathrm{KOH}, \mathrm{NaOH}, \mathrm{KF})$ and acid $\left(\mathrm{H}_{2} \mathrm{SO}_{4}, \mathrm{HCl}, \mathrm{HSO}_{3} \mathrm{CI}\right)$ to tune desirable characteristics in the catalyst [116]. Alkaline functionalisation is an approach to improving the surface area and pore volume of the catalyst [117], while acid functionalisation will improve the acidic properties of the catalyst. Thereby, the acid functionalised $\mathrm{CaO}$ catalyst is capable of converting high FFA feed to biodiesel via esterification [118]. This is evinced by Nurhayati et al. finding [118], with sulfonated blood clam shell catalyst ( $\mathrm{CaO}$ treated by $3 \mathrm{M} \mathrm{H}_{2} \mathrm{SO}_{4}$ ) effectively converting both FFA and TAG to a high yield of biodiesel 
( $97 \%)$ under reaction conditions: $12: 1 \mathrm{MeOH}$ :oil molar ratio, $60^{\circ} \mathrm{C}$ for $3 \mathrm{~h}$ using $1 \mathrm{wt} . \%$ catalyst loading. Cho and Seo [119] also treated quail eggshell with $0.005 \mathrm{M} \mathrm{HCl}$ for $2 \mathrm{~h}$ and maximum biodiesel conversion of $89 \%$ was obtained by transesterification of palm oil at $65{ }^{\circ} \mathrm{C}$ within $2 \mathrm{~h}$ using $1 \mathrm{wt} . \%$ of catalyst and 12:1 methanol:oil molar ratio. Other cases of high FFA microalgae oil were studied by Syazwani et al. [120] with the utilisation of $\mathrm{CaO}$ derived from Angel Wing shell catalyst. The $\mathrm{CaO}$ catalyst was modified via sulfuric acid treatment and the result indicated that the CAWS- ${ }_{(\mathrm{x})} \mathrm{SO}_{4}$ catalysts were capable of converting the palm fatty acid distillate (PFAD) (FFA: 92\%) to biodiesel rich fuel. The optimal biodiesel conversion (98\%) from the PFAD was acquired at the reaction temperature of $80^{\circ} \mathrm{C}, 15: 1 \mathrm{MeOH}: \mathrm{PFAD}$ molar ratio and $5 \mathrm{wt} . \%$ catalyst loading for a $3 \mathrm{~h}$ reaction time [121].

As discussed previously, the alkaline functionalisation approach has been extensively investigated to improve the textural properties of the $\mathrm{CaO}$ [117]. This was confirmed by Nurdin et al. [122] in the transesterification of castor oil. Obviously, $\mathrm{KOH} / \mathrm{CaO}$ derived from mussel shell shows high surface area and pore volume properties. The authors reported the catalyst's reactivity, capable of maintaining biodiesel yield to $\sim 80 \%$ for four reaction runs under optimal condition: 6:1 MeOH:oil molar ratio, $2 \mathrm{wt}$ \% catalyst loading, $60{ }^{\circ} \mathrm{C}$ for $3 \mathrm{~h}$. Other than $\mathrm{KOH}, \mathrm{CaO}$ was also modified by alkaline potassium fluoride (KF). Thi \& Myat [123] treated the waste eggshell derived $\mathrm{CaO}$ with $\mathrm{KF}$ in order to promote stronger active sites formation. KF was functionalized with $\mathrm{CaO}$ via a wet-incipient method under microwave irradiation. The authors remarked that the composition of $\mathrm{Ca}$ and $\mathrm{KF}$ in $\mathrm{KF} / \mathrm{CaO}$ catalyst influenced the catalytic transesterification activity. The study indicated that the maximum yield of biodiesel was not achieved with the high amount of KF, due to over-coating of the catalyst surface by potassium and fluoride components. Biodiesel production was performed at the optimum condition with 8:1 MeOH:oil molar ratio, $5 \mathrm{wt} . \%$ catalyst loading at $65^{\circ} \mathrm{C}$ for $2.5 \mathrm{~h}$ with maximum biodiesel yield of $\sim 95 \%$, while a reusability study showed that $\mathrm{KF} / \mathrm{CaO}$ only can be reused for up to four runs with biodiesel yield $>80 \%$. The stability of $\mathrm{KF} / \mathrm{CaO}$ was further compared with pure $\mathrm{CaO}$, when $\mathrm{KF} / \mathrm{CaO}$ rendered better stability with less Ca leaching. Beyond that, Komintarachat \& Chuepeng functionalised $\mathrm{KCl}$ on green mussel-derived $\mathrm{CaO}\left(\mathrm{CaO}_{\text {waste }}\right)$ for transesterification of WCO under optimum conditions of $4 \mathrm{wt} . \%$ catalyst loading, EtOH:oil molar ratio of $10: 1,80{ }^{\circ} \mathrm{C}$ within $3 \mathrm{~h}$ [124]. The optimum biodiesel yield obtained was $97 \%$. A comparison study was performed between $\mathrm{CaO}_{\text {com }}$, synthesised $\mathrm{CaO}$ calcined from green mussel shell $\left(\mathrm{CaO}_{\text {waste }}\right)$ and $\mathrm{KCl}$-impregnated $\mathrm{CaO}$ waste $\left(\mathrm{KCl} / \mathrm{CaO}_{\text {waste }}\right)$, when $\mathrm{KCl} / \mathrm{CaO}_{\text {waste }}$ catalyst was shown as most effective in facilitating the transesterification reaction.

Instead of metal oxide dopant and acid-alkaline functionalization approaches, the $\mathrm{CaO}$ can be modified via a hydration-dehydration technique. The hydration-dehydration of $\mathrm{CaO}$ catalyst involves the replacement of $\mathrm{CO}^{2-}$ with $\mathrm{OH}^{-}$form Brønsted basic sites [125]. Ahmad et al. [126] treated waste eggshell-derived $\mathrm{CaO}$ with the hydration-dehydration method for the transesterification of algal biomass. With this method, the calcined eggshells were refluxed in the water at $60^{\circ} \mathrm{C}$ for $6 \mathrm{~h}$, followed by partial thermal treatment. Noteworthy, hydroxylation reaction occurred during water treatment, which simultaneously promoted the hydroxide surface on $\mathrm{CaO}$. When the water-treated samples were sent for partial dehydration process, the attached water molecules were removed from the catalyst lattice, which led to the fractionation of crystallites to smaller sizes (higher surface area) and generation of higher porosity [100]. Ahmed further reported that the yield of biodiesel obtained was 93\% under condition of $2 \mathrm{wt} . \%$ catalyst loading, 30:1 MeOH:Algal biomass at $60{ }^{\circ} \mathrm{C}$ for $3 \mathrm{~h}$ [126]. The authors reported that this catalyst was stable for six cycles with an average yield of $>85 \%$. A series of $\mathrm{Zn}$ doped $\mathrm{CaO}$ derived from eggshell (0.5-2 wt. $\% \mathrm{Zn}^{2+}$ concentration in $\mathrm{CaO}$ ) nano-catalysts was prepared and employed in the transesterification of WCO [114]. Maximum biodiesel conversion of $97 \%$ was recorded under the reaction conditions of 20:1 MeOH:oil molar ratio, $5 \mathrm{wt} . \%$ catalyst loading, $65{ }^{\circ} \mathrm{C}$ reaction temperature and $4 \mathrm{~h}$ of reaction time. Recently, Niju et al. utilized modified $\mathrm{CaO}$ derived from eggshell for transesterification of $\mathrm{WCO}$ and the result showed that biodiesel 
conversion at $94 \%$ with reusability $>90 \%$ for six runs [127]. Similarly, Niju's research study also discovered a high biodiesel yield (97\%) from transesterification of WCO over calcination-hydration-dehydration modified $\mathrm{CaO}$. The $\mathrm{CaO}$ was produced from Tellina tenuis shells [128]. Based on Niju's observation, an excellent porous structure of the $\mathrm{CaO}$ catalyst was obtained from this method, and the large surface area confirmed the enhancement of the transesterification process [54,129]. Although several studies proved that the $\mathrm{CaO}$ synthesized from the hydration-dehydration approach exhibited excellent transesterification activity, this catalyst is chemically unstable as it possesses low reusability. This was in accordance with our former research group finding [100], where the modified $\mathrm{CaO}$ catalyst from natural waste clamshell (Meretrix meretrix) was used for transesterification of palm oil. The $\mathrm{CaO}$ modified via hydration-dehydration treatment showed high biodiesel conversion (98\%) under a reaction time of $2 \mathrm{~h}, 1 \mathrm{wt} . \%$ catalyst loading and 9:1 methanol: oil molar ratio. Unfortunately, the catalyst was only capable of maintaining two runs of reaction with $98 \%$ biodiesel yield. Instability of the catalyst is due to the presence of active $\mathrm{Ca}(\mathrm{OH})_{2}$ phases, which partially decomposed during the transesterification reaction. Interestingly, Chen's group [130] replaced the water medium with an alcohol medium during the catalyst's hydration treatment for the purpose of better $\mathrm{Ca}(\mathrm{OH})_{2}$ stability during transesterification. The modified abalone shell-derived $\mathrm{CaO}\left(\mathrm{M}-\mathrm{CaO} \_100\right)$ was treated by using ethanol in the hydration-dehydration method. Similarly, the ethanol acted as water that partially hydrated $\mathrm{CaO}$ to $\mathrm{Ca}(\mathrm{OH})_{2}$ species, the results showing high basic density and excellent textural properties. The study further reported that a $7 \mathrm{wt}$ \% catalyst loading, 9:1 MeOH:oil molar ratio and a reaction time of $2.5 \mathrm{~h}$ is required to obtain a biodiesel yield of $96 \%$. In detail, after the fifth run, the biodiesel yield of the M-CaO_100 catalysed reaction dropped from $95.0 \%$ to $88.5 \%$. The loss in activity during the reusability process was due to formation of calcium diglyceroxide on the catalyst surface, which resulted in unfavourable reaction between $\mathrm{Ca}(\mathrm{OH})_{2}$ with the by-product glycerol. Overall, the results suggested that the ethanol treatment did not provide a significant stability effect to reduce $\mathrm{Ca}^{2+}$ leaching behaviour for $\mathrm{M}-\mathrm{CaO} \_100$. Based on the above discussion, it is still a great challenge to identify a highly stable solid $\mathrm{CaO}$ derived from waste shell for biodiesel reaction.

It can be noted that not all of the literature studies on modification of $\mathrm{CaO}$ showed a significant impact on the stability of the catalyst for transesterification of plant-based oil. However, it has confirmed that the $\mathrm{CaO}$ catalysts were ineffective in transforming high FFA feedstock to biodiesel. This is due to the partial homogeneous state of $\mathrm{CaO}$ (dissolution of $\mathrm{Ca}^{2+}$ ) and lead to a big challenge for large scale biodiesel production. The high basicity of $\mathrm{CaO}$ catalyst is sensitive to the acid characteristics of FFA and the moisture content in low grade feedstock. Therefore, FFA content in oils needs to be kept as low as possible $(0.5-1 \%)$ to hinder the saponification reaction, because otherwise it will react with the $\mathrm{Ca}^{2+}$ to produce soap as by-product. Excessive soap formation inhibits the biodiesel-glycerol phase separation and thus reduces biodiesel yield drastically. Due to this, modification of $\mathrm{CaO}$ is necessary to generate the acid sites in the catalyst system. The presence of Lewis/Bronsted acid sites is able to esterify the presence of FFA in low-grade feedstock into ester product without reducing the transesterification reactivity of the catalyst. 
Table 1. Summary of various types of waste shell derived catalysts in transesterification of biodiesel production.

\begin{tabular}{|c|c|c|c|c|c|c|c|c|c|c|c|}
\hline \multirow[b]{2}{*}{ Waste Shells } & \multirow[b]{2}{*}{ Feedstocks } & \multirow[b]{2}{*}{ FFA (\%) } & \multirow[b]{2}{*}{ Catalyst } & \multicolumn{2}{|c|}{ Calcination } & \multicolumn{3}{|c|}{ Transesterification } & \multirow[b]{2}{*}{$\begin{array}{c}\text { Conversion/Yield } \\
(\%)\end{array}$} & \multirow[b]{2}{*}{$\begin{array}{c}\text { Reusability } \\
(\%)\end{array}$} & \multirow[b]{2}{*}{ Ref. } \\
\hline & & & & $\begin{array}{c}\text { Temperature } \\
\left({ }^{\circ} \mathrm{C}\right)\end{array}$ & $\begin{array}{c}\text { Duration } \\
\text { (h) }\end{array}$ & MeOH:Oil & $\begin{array}{c}\text { Catalyst } \\
(w t \%)\end{array}$ & Duration (h) & & & \\
\hline Angel Wing Shell & Microalgae Oil & 8.03 & $\mathrm{CaO}$ & 805 & 2 & $150: 1$ & 9 & 1 & 84.11 & 3 & [120] \\
\hline Capiz Shell & Refined Palm Oil & 0.10 & $\mathrm{CaO}$ & 900 & 2 & $8: 1$ & 3 & 6 & 92.83 & 3 & [85] \\
\hline Chicken Eggshell & Jatropha Oil & 6.25 & $\mathrm{ZnO}-\mathrm{CaO}$ & 900 & 4 & $12: 1$ & 5 & 1 & 98.20 & 4 & [109] \\
\hline Cockle Shell & Palm Oil & 0.10 & $\mathrm{CaO}$ & 1000 & 4 & $9: 1$ & 10 & 4 & 94.47 & 4 & [86] \\
\hline Crab Shell & Jatropha Oil & 6.25 & $\mathrm{CaO}$ & 900 & 2 & $18: 1$ & 4 & $\begin{array}{c}5(\mathrm{~min}) \\
\text { (Microwave) }\end{array}$ & 92.11 & 5 & [93] \\
\hline Eggshell & Palm Oil & 0.55 & $\mathrm{CaO}$ & 800 & 4 & $18: 1$ & 15 & $\begin{array}{c}4(\mathrm{~min}) \\
\text { (Microwave) }\end{array}$ & 96.70 & 5 & [87] \\
\hline Eggshell & Camelina Sativa Oil & 1.60 & $\mathrm{CaO}$ & 900 & 3 & $12: 1$ & 1 & 3 & 97.20 & - & [74] \\
\hline Eggshell & Nahor Oil & $<1$ & Li Doped CaO & 800 & 2 & $10: 1$ & 5 & 4 & 95.00 & 3 & [106] \\
\hline Eggshell & WCO & - & $\mathrm{MgO} / \mathrm{CaO}$ & 900 & 4 & 16.7:1 & 4.5 & 7 & 98.30 & 6 & [105] \\
\hline Eggshell & Eucalyptus Oil & 0.56 & $\mathrm{ZnO} / \mathrm{CuO}$ & 900 & 4 & $6: 1$ & 5 & 2.5 & $>90$ & 7 & [110] \\
\hline Eggshell & Microalgal Oil & 0.37 & $\mathrm{Co} / \mathrm{CaO}$ & 900 & 4 & - & 1.5 & 4 & 98 & 3 & {$[112]$} \\
\hline Eggshell & Palm Oil & 0.10 & $\mathrm{KF} / \mathrm{CaO}$ & 900 & 3 & $8: 1$ & 5 & 2.5 & $\sim 95$ & 4 & [123] \\
\hline Eggshell & Algal Biomass & - & $\mathrm{HD} \mathrm{CaO}$ & 900 & 3 & $30: 1$ & 2.1 & 3 & 93.44 & 6 & [126] \\
\hline Grooved Razor Shell & WCO & 0.66 & $\mathrm{CaO}$ & 900 & - & $15: 1$ & 5 & 3 & 94.00 & 6 & {$[88]$} \\
\hline Mussel Shell & Palm Oil & 0.10 & $\mathrm{CaO}$ & 1000 & 4 & $9: 1$ & 10 & 4 & 97.23 & 4 & [86] \\
\hline Mussel Shel & Castor Oil & 1.00 & $\mathrm{KOH} / \mathrm{CaO}$ & 1000 & 1 & $6: 1$ & 2 & 3 & 91.17 & 5 & [122] \\
\hline Oyster Shell & WCO & 1.00 & $\mathrm{CaO}$ & 1000 & 2 & $9: 1$ & 6 & $\begin{array}{c}3 \\
\text { (Microwave) }\end{array}$ & 87.30 & - & [90] \\
\hline Quail Eggshell & Jatropha Oil & 6.25 & $\mathrm{CaO}$ & 900 & 2 & $18: 1$ & 4 & $\begin{array}{c}5(\min ) \\
\text { (Microwave) }\end{array}$ & 92.78 & 5 & [93] \\
\hline Quail Eggshell & Palm Oil & 0.10 & $\mathrm{H}_{2} \mathrm{SO}_{4} / \mathrm{CaO}$ & 800 & - & $12: 1$ & $0.01(\mathrm{~g})$ & 2 & 89 & - & [119] \\
\hline Scallop Shell & Palm Oil & 0.10 & $\mathrm{CaO}$ & 1000 & 4 & $9: 1$ & 10 & 4 & 96.68 & 4 & [86] \\
\hline Scallop Shell & WCO & 0.62 & $\mathrm{CaO}$ & 1000 & 2 & $6: 1$ & 5 & 2 & 86.00 & 4 & [91] \\
\hline Snail Shell & Soybean Oil & 0.10 & $\mathrm{CaO}$ & 900 & 4 & $6: 1$ & 3 & $7\left(28^{\circ} \mathrm{C}\right)$ & 98.00 & 9 & [92] \\
\hline $\begin{array}{c}\text { Turbonilla Striatula } \\
\text { Shell }\end{array}$ & WCO & $<1$ & Ba Doped $\mathrm{CaO}$ & 900 & 3 & $6: 1$ & 1 & 3 & $>98 \%$ & 4 & [104] \\
\hline
\end{tabular}




\section{Mechanism of $\mathrm{CaO}$ Catalysed Transesterification}

The most usual foundations for heterogeneous transesterification mechanisms are Eley-Rideal (ER) and Langmuir-Hinshel (LH) [131]. Both mechanisms are a theoretical model of bimolecular chemical reaction that can take place on a solid surface. In the ER mechanism, an atom or molecule adsorbs onto the surface, followed by direct reaction with another atom or molecule attached to the catalyst's surface. However, in the LH mechanism two atoms or molecules are initially adsorbed on the surface of the catalyst, and diffuse across the surface until they are close enough to interact [132]. The ER mechanism for the transesterification process involves three steps (Figure 3a): (i) methanol (M) is first adsorbed on the active site of the catalyst surface (S); (ii) then the triglyceride (TG) reacts with the methoxide ion to form fatty acid methyl ester (FAME) and glycerol (GL); and (iii) finally the glycerol is desorbed from the surface of the catalyst active site [133]. In the case of the LH mechanism, the reaction involves a five-step process. In the first two steps, the methanol and oil are individually adsorbed on the surface of the catalyst and generate two different active sites for further reaction. Both reactants will further react with each other in the following step, which is known as the determining step. The glycerol and FAME produced from the determining step is then desorbed separately in the last two-step of the transesterification process (Figure 3b) [133].
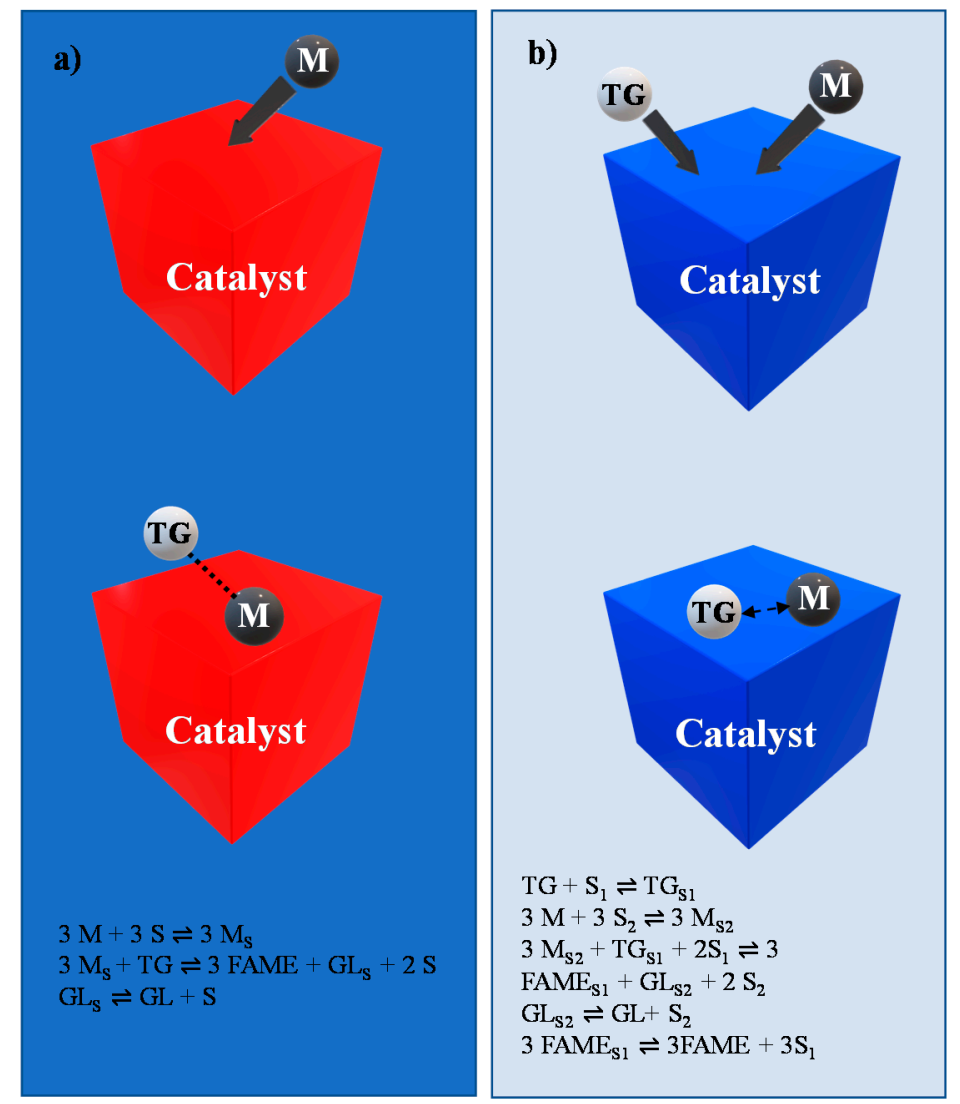

Figure 3. (a) Eley-Rideal (ER) mechanism and (b) Langmuir-Hinshel (LH) mechanism (data adapted from http://www.chem.ucl.ac.uk/cosmicdust/er-lh.htm).

As mentioned in the previous section, $\mathrm{CaO}$ is the most studied alkaline-earth metal oxide catalyst for transesterification. The presence of conjugated oxygen anions on the surface of $\mathrm{CaO}$ generates strong Lewis basicity that greatly affects the catalytic activity during the transesterification reaction [134]. The generation of basic sites on the oxide phase of the Ca-O surface plays role in abstracting the protons from the organic matter, which trigger a basic catalytic reaction [135]. Figure 4a illustrates the mechanism of $\mathrm{CaO}$ catalysed transesterification. The presence of basic active sites in the $\mathrm{CaO}$ catalyst abstracts 
the proton from methanol to form a higher catalytic activity methoxide anion $\left(\mathrm{CH}_{3} \mathrm{O}^{-}\right)$. The $\mathrm{CH}_{3} \mathrm{O}^{-}$then carries out a nucleophilic attack on the carbonyl carbon of triglyceride to form the tetrahedral alkoxy carbonyl intermediate. The rearrangement of this unstable intermediate results in the decomposition of the diglyceride anion and the formation of fatty acid methyl ester (biodiesel). Finally, the proton attracts the diglyceride anion to produce diglyceride and regenerate the active site of the $\mathrm{CaO}$ catalyst. This mechanism is then repeated twice for another two-carbonyl carbon and glycerol is yielded as a byproduct. Both the first and second steps of the complex process of the transesterification of triglycerides and diglycerides with methanol are always much faster than the reaction of monoglycerides, which ultimately produces biodiesel and glycerol [136].

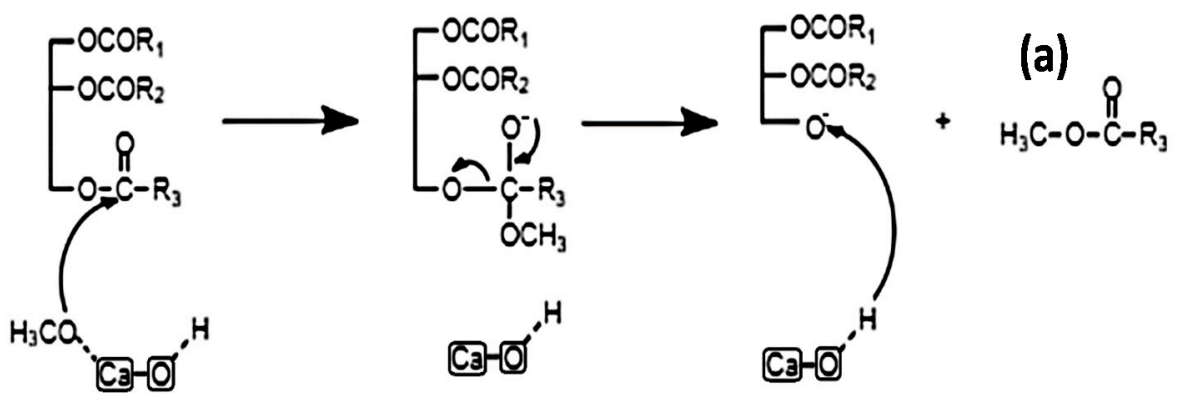

(b)

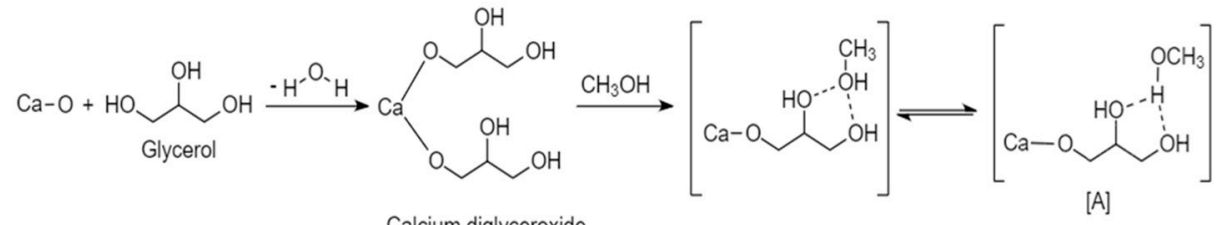
Calcium diglyceroxide

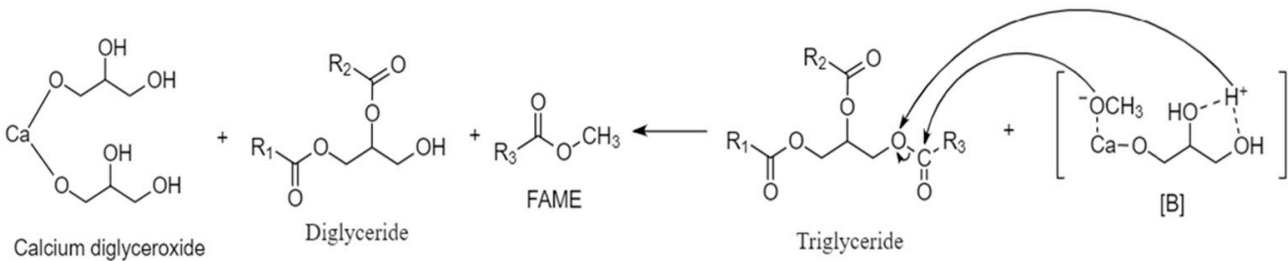

Figure 4. (a) Mechanism of $\mathrm{CaO}$ catalyzed transesterification (data adapted from [21]) (b) Mechanism of CaO reacted with by-produced glycerol in production of fatty acid methyl ester (FAME) (adapted from [137]).

The generated by-product glycerol is a trihydric alcohol, which tend to react with $\mathrm{CaO}$ via the dihydroxylation process to form $\mathrm{CaO}$-glycerol complexes, known as calcium diglyceroxide $\left(\mathrm{Ca}\left[\mathrm{O}(\mathrm{OH})_{2} \mathrm{C}_{3} \mathrm{H}_{5}\right]_{2}\right)$. The catalytic activity of these complexes is slightly lower than $\mathrm{CaO}$ in transesterification. Figure $4 \mathrm{~b}$ shows the mechanism of $\mathrm{CaO}$ reacted with glycerol. The protons of the methanol are abstracted by two of the - $\mathrm{OH}$ groups located next to each other in calcium diglyceroxide and contribute to the establishment of intermolecular hydrogen bonding to generate species A and B. Species B then reacts with triglycerides to yield biodiesel. Calcium diglyceroxide is finally regenerated and makes the process self-repeating, which further enhances the transesterification reaction [131,135,137].

\section{Recent Progress of Reactors Used for $\mathrm{CaO}$ and Waste Shell Catalyzed Transesterification}

Generally, the lab-based transesterification and esterification process is conducted by using a three-neck round-bottom flask fitted with a reflux condenser, magnetic stirrer and a thermometer with water cooling condenser (Figure 5a) $[114,138]$. Notably, the ma- 
jority of the waste shell catalyzed transesterification focused on the reflux distillation system $[129,139]$. The conventional heating system for biodiesel production has shown some drawbacks. Limitations typically are the dependence on the thermal conductivity of the material, the heterogenic heating of the surface and specific heat. To date, these reflux distillation techniques are being replaced by more advanced systems.

In biodiesel production, proper mixing is critically important to create sufficient contact between oil and alcohol. In this context, ultrasonication helps by facilitating the liquid-liquid interfacial area through emulsification, which can effectively generate vapour bubbles and cavitation bubbles in viscous liquids (Figure 5b) $[140,141]$. The ultrasound in the chemical processing enhances both the mass transfer and chemical reactions, offering the potential for shorter reaction times, cheaper reagents and less extreme physical conditions [142,143]. In Teixeira et al. [142] on transesterification of beef tallow, it was reported that using ultrasound irradiation shortens the reaction time (70 s). Obviously, the transesterification of beef tallow using ultrasound irradiation had a biodiesel conversion (92\%) that was comparable to the conventional method (reflux distillation system) that needed $1 \mathrm{~h}(91 \%)$. Note that the quality of the biodiesel was like biodiesel produced with the conventional method. These finding suggest that the process involving ultrasonic irradiation could be a feasible and effective method for the production of good quality biodiesel from beef tallow. Recently, Wilayat et al. [144] produced biodiesel from WCO by using CaO assisted by ultrasonic wave. About $1-4.4 \%$ of catalyst is used for the biodiesel reaction with the presence of an ultrasonic wave generated from an ultrasonic cleaner at 28 and $42 \mathrm{kHz}$ of frequency. The results have shown a highest methyl ester yield at $~ 90 \%$ using 9:1 MeOH:oil molar ratio and a frequency of $40 \mathrm{kHz}$. Clearly, the increment frequency of the ultrasonic wave causes an increase in the transesterification rate. The ultrasonic-assisted transesterification of palm oil in the presence of $\mathrm{CaO}$ was investigated by Mootabadi [145]. The reaction process was carried out with $20 \mathrm{kHz}$ ultrasonic cavitation, reaction time (10-60 min), $\mathrm{MeOH}$ to palm oil molar ratio (3:1-15:1), catalysts loading (0.5-3\%) and varying of ultrasonic amplitudes (25-100\%). At optimum conditions of $60 \mathrm{~min}, 95 \%$ of biodiesel yield was achieved as compared to $2-4 \mathrm{~h}$ under the conventional reflux process. A further study on ultrasonic-assisted transesterification of palm oil with the aid of waste ostrich eggshell-derived $\mathrm{CaO}$ was reported in the earlier literature [146]. Under ultrasonic conditions, $\sim 93 \%$ of biodiesel yield was achieved under the optimal condition: reaction time: $69 \mathrm{~min} ; \mathrm{MeOH}$ :oil to oil ratio of 9:1, catalyst loading of $8 \mathrm{wt} . \%$.

Microwave irradiation provides an alternative energy source suitable for use in heating of the transesterification process. During transesterification of oil-based triglyceride with alcohol, the microwave system is able to activate the smallest variance in degree of polar molecules and ions, such as alcohol $(\mathrm{R}-\mathrm{OH})$, with a continuously changing magnetic field. The varying electric field resulted in an interaction between the triglyceride and alcohol ions ( $\mathrm{R}-\mathrm{O}-$ ), thereby rapid rotation occurs between the reaction medium, which further generates heat attributed to molecular friction. Hereafter, the microwave-assisted system will accelerate the generation of heat and pressure from the reaction medium, which supports further decomposition and re-structuring of the molecular structure, and increases the mass transfer rate. It can be suggested that the high conversion of triglyceride into desired biodiesel will be attained within a shorter reaction period $[147,148]$. It is noteworthy that the former literature also revealed that the microwave system might enhance reaction rate, purity and yield of product in biodiesel synthesis $[149,150]$. Figure $5 c$ shows an example of a modified Samsung $1000 \mathrm{~W} 2450 \mathrm{~Hz}$ household microwave oven. Two holes were drilled in the top of the domestic microwave oven, one to position the stirrer and the other to shift the thermocouple inside the microwave. The microwave was fitted with a mechanical stirrer, which was powered by a motor to replace the carousel. The thermocouple was attached to a USB-5104 4-channel thermocouple logger. For this experiment, a one-litre beaker was supplied and a separation funnel was used to isolate the biodiesel from the reaction mixture. The reaction analysis was conducted by varying microwave power input, catalytic loading and methanol to oil molar ratio. Although the application of a modi- 
fied household microwave for biodiesel synthesis is an effective and low-budget study, its application is still not considered as ideal for scientific experiments due the lack safety features such as overpressure guard, temperature control regulator and power control, etc. Due to this concern, researchers continue to discover the potential of a microwave-assisted system for biodiesel synthesis $[93,151,152]$. The efficiency of the microwave reaction system has been further proved by Liou and Chung in the microwave-assisted transesterification of Jatropha oil over $\mathrm{KOH}$ impregnated $\mathrm{CaO}$ catalyst [151]. The optimum condition for producing the highest yield of biodiesel was as follows: $8.42 \mathrm{MeOH}$ :oil molar ratio, 3.17\% catalyst loading and total reaction time of $67.9 \mathrm{~min}$. The average conversion for three repeated experimental runs at optimum condition was found to be $97.1 \%$. The biodiesel obtained also had properties satisfying the desired standards. Similarly, Zamberi and his partners reported the utilization of $\mathrm{CaO}$ derived from waste cockles on the biodiesel production of WCO via a microwave heating system. Within $4 \mathrm{~min}$, more than $95 \%$ yield concentration was recorded through the microwave irradiation method [153]. This was based on Buasri and Loryuenyong's findings on biodiesel production from jatropha oil over $\mathrm{CaO}$ derived from eggshell via a microwave-assisted reaction system [93]. Apparently, rapid transesterification reaction is observed which yielded a conversion of oil of nearly $94 \%$, reaction time $5 \mathrm{~min}$, microwave power $800 \mathrm{~W}$, MeOH:oil molar ratio 18:1, and catalyst loading $4 \mathrm{wt} . \%$. Overall, based on these studies, it is highly affirmed that the transesterification assisted by the microwave-assisted method improved biodiesel yield, quality and reaction rate. When comparing the technology effectiveness of biodiesel production by using the ultrasound irradiation, ultrasonic wave and microwave reaction systems, it was observed that the transesterification process under ultrasound irradiation is much faster. This is due to a collapse of the cavitation bubbles and ultrasonic jets that impinge feedstock to methanol, disrupting the phase boundary and causing emulsification. Overall, the ultrasound irradiation method is the most promising alternative heating source for the biodiesel industry.
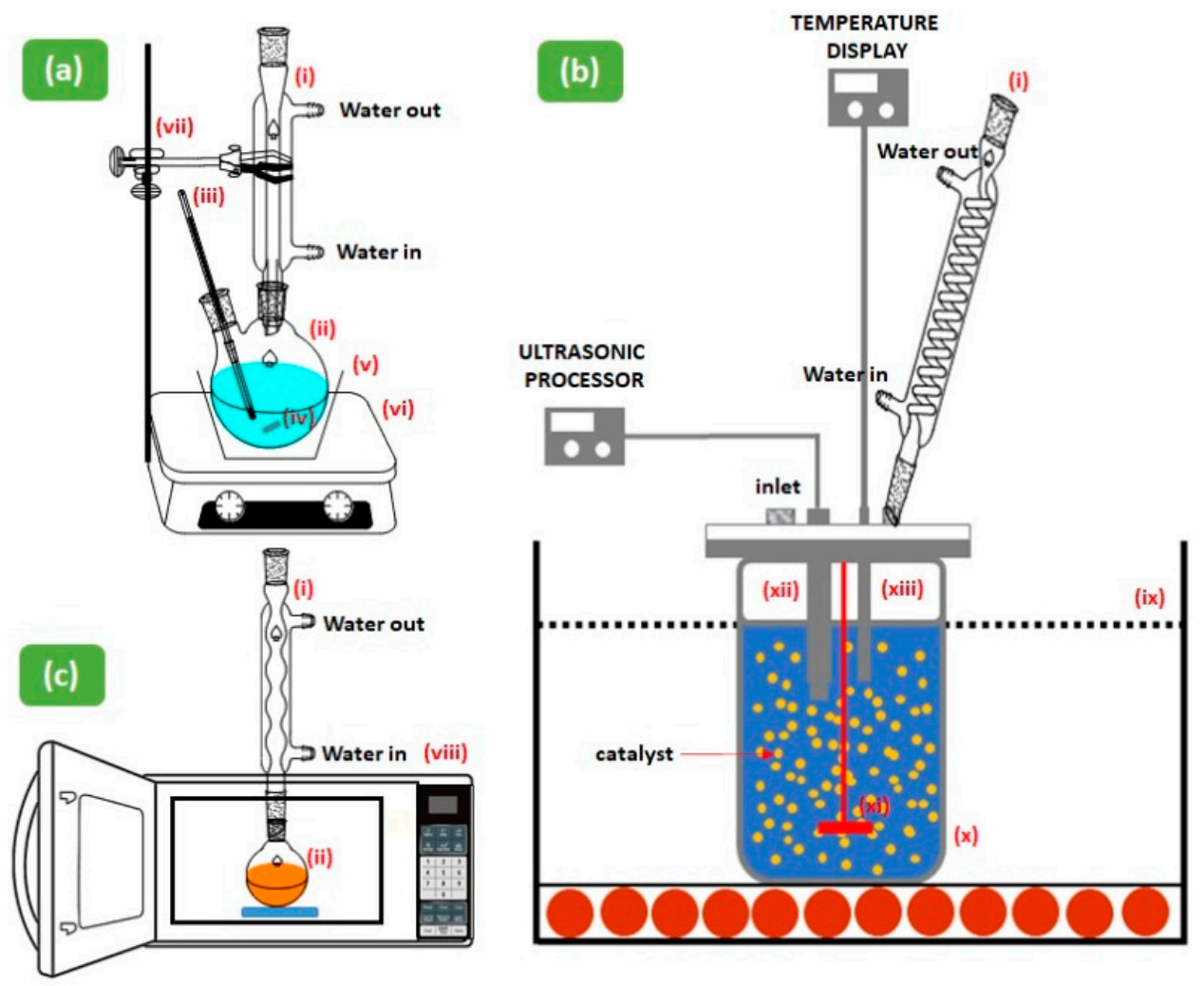
i. Condenser
ii. Round bottom flask
iii. Thermometer
iv. Stirring bar
v. Paraffin oil
vi. Hot plate
vii. Retort stand
viii. Microwave
ix. Water bath
x. Vessel
xi. Magnetic stirrer
xii. Ultrasonic probe
xiii. Probe

Figure 5. (a) Set up of transesterification reaction, (b) Component part of ultrasonic-assisted transesterification (adapted from [141]) (c) Transesterification by using a batch process within a modified Samsung 1000 W 2450 Hz household microwave oven (adapted from [152]). 


\section{The Challenge of Waste Shell-Derived Catalyst and Advance Reactors for the Biodiesel Industry}

Calcium-rich waste shell materials as a low-cost green resource are readily available around the world. Utilization of the waste shell modified catalyst is a tremendous prospect for the biodiesel industry. Yet, there are still challenges for further improvement on an industrial scale. This is due to the instability of $\mathrm{CaO}$ catalyst which commonly suffers from $\mathrm{Ca}^{2+}$ leaching problem [135]. Other problems such as low surface area, water sensibility, leaching of active sites by glycerol, and competing with soap-forming side reactions have afflicted the utilization of waste shell-derived $\mathrm{CaO}$ catalysts. According to the research work done by Kouzu and Hidaka, the leached $\mathrm{Ca}^{2+}$ is increased when there is excess water content in the reaction medium [135]. This is noteworthy to mention, since $\mathrm{Ca}^{2+}$ easily dissolves and leaches into the reaction product; hence, additional advance separation and purification are needed to extract $\mathrm{Ca}^{2+}$ ions from the biodiesel. Thus, it will produce a significant volume of wastewater during the purification process. Furthermore, the $\mathrm{CaO}$ catalyst was often easily deactivated by water or $\mathrm{CO}_{2}$ [154]. Due to the adsorption of $\mathrm{CO}_{2}$ and humidity, the $\mathrm{CaO}$ surface is readily contaminated by moisture attachments and transforms to $\mathrm{CaCO}_{3}$ and $\mathrm{Ca}(\mathrm{OH})_{2}$, respectively. This $\mathrm{Ca}(\mathrm{OH})_{2}$ phase will apparently act as a partial homogenous catalyst in the transesterification reaction, hence leading to the increment of $\mathrm{Ca}^{2+}$ leaching species. Based on the above discussion, the instability of $\mathrm{CaO}$ derived from waste shells can be resolved by combining the $\mathrm{CaO}$ with other chemical compounds such as AMOs, TMOs and functionalization approaches. Moreover, alkaline metal and transition metal are considered inexpensive materials, which do not significantly contribute to the overall production cost when the catalyst can be reuses for many runs under a simple purification process as compared to a homogeneous [154].

In the case of reactor design, although intensification systems such as microwave- and ultrasonication-assisted transesterification offer the opportunity to save operation time as well as improve productivity, one of the limitations of microwave scale-up technology for industrial purposes is the restricted penetration depth of microwave irradiation into absorbing materials. Weissman et al. [155] reported that the penetration depth of microwave irradiation is limited to $2-5 \mathrm{~cm}$ and therefore the vessel size cannot be expanded unrestrictedly. High microwave power may also lead to rapid input of energy into the reaction and to overheating. Another issue is related to the homogeneity (inhomogeneity may lead to hot spots and product degradation) and stability of solvents, reagents, and products at temperatures higher than $200^{\circ} \mathrm{C}$. The continuous occurrence of instability and degradation of the reaction mixture will result in safety issues.

As a consequence of microwave input, the system will result in a rise in pressure during the reaction; hence the construction materials for the microwave reactor must be able to withstand high temperatures and high pressure (e.g., $250{ }^{\circ} \mathrm{C}, 20 \mathrm{bar}$ ). Based on this fact, it is believed that the implementation of ultrasonication scale-up technology will face additional issues including the implementation of the ultrasonic homogenization system. This technique is very important in producing chemical and physical effects that arise from the collapse of cavitation bubbles. As reported by Shinde and Kaliaguine, high-frequency ultrasound $(\sim 40 \mathrm{kHz})$ will rapidly increase the rate of transesterification reaction and hence increase biodiesel yield [140]. As a consequence, the ultrasound amplitude and power should be carefully controlled for up-scaling purposes. Noteworthy to mention is that, when comparing microwave- and ultrasonication-assisted method, the ultrasound offers a much cheaper process and less extreme physical conditions. Despite the large number of studies that have investigated ultrasonic-assisted biodiesel production [142,156], it appears that there has been no thorough study conducted on the use of ultrasound for improving biodiesel production for scale-up purposes.

\section{Conclusions}

Natural waste shells are rich in calcium that is potentially convertible into Ca-based catalyst for biodiesel synthesis via transesterification/esterification pathways. Generally, 
the calcium is present in the form of calcium carbonate (95-99\%), and further treatment is required in order to expose the calcium active phases (e.g., oxide or hydroxide phases) for further reaction. The waste shell-derived $\mathrm{CaO}$ or $\mathrm{Ca}(\mathrm{OH})_{2}$ shows similar characteristics to the conventional form, such as basicity and surface area. It was noted that both properties, especially the high basicity density and strong basic strength of catalyst, greatly enhance the transesterification rate for biodiesel production. However, the present form of waste shell-derived catalysts is still limited in use for feedstock with high free fatty acid or high moisture content found in non-edible oil and waste cooking oil. Unfavorable side reactions occurred between Ca from waste shell-derived catalysts with FFA or moisture to form unwanted soap product, and the ease of dissolution of catalyst by $\mathrm{Ca}$ leaching, respectively. Thus, further modification of waste shell-derived catalysts has been extensively studied by researchers to improve the stability of catalyst, as well as resist FFA/moisture in the feedstock. The modification can be performed via incorporation of alkaline metal oxide, transition metal oxide, and functionalization with chemicals $(\mathrm{KOH}, \mathrm{NaOH}, \mathrm{KF}$, $\mathrm{H}_{2} \mathrm{SO}_{4}, \mathrm{HCl}, \mathrm{HSO}_{3} \mathrm{CI}$ ) to tune the acidity-basicity of active sites and textural properties of waste shell-derived catalysts. The findings show that the transesterification reactivity significantly improves with higher biodiesel yield, as well as a better reusability profile. Other than modifying the waste shell-derived catalyst, intensification of transesterification was performed by using microwave- or ultrasonic-assisted technology to replace the conventional reflux heating, with short operation time as well as clean biodiesel product. However, implementation of this technology for scale up biodiesel production must meet the challenge of construction and operating cost. Thus, continuous development of reactor technology for biodiesel production is in progress to strive for better ecological processes.

Author Contributions: Conceptualization, N.A.M.; validation, H.V.L.; data curation, M.S.M.; writing-original draft preparation, H.K.O., X.N.K.; writing-review and editing, N.A.M., H.V.L., H.C.O., M.S.M. and Y.H.T.-Y.; supervision, N.A.M.; funding acquisition, N.A.M., A.A.A., F.A.A. and H.V.L. All authors have read and agreed to the published version of the manuscript.

Funding: This research was funded by Galakan Penyelidik Muda (GGPM) (GGPM-2020-015), University of Malaya's Research Grant:MOHE-Top 100 (IIRG)-IISS (IIRG002A-2020IISS), International Scientific Partnership Program ISPP at King Saud University for funding this research work through ISPP-142.

Institutional Review Board Statement: Not applicable.

Informed Consent Statement: Not applicable.

Acknowledgments: We are grateful to the financial support from Galakan Penyelidik Muda (GGPM) (GGPM-2020-015), University of Malaya's Research Grant:MOHE-Top 100 (IIRG)-IISS (IIRG002A2020IISS) and International Scientific Partnership Program ISPP at King Saud University for funding this research work through ISPP-142.

Conflicts of Interest: The authors declare no conflict of interest.

\section{References}

1. Lee, S.Y.; Sankaran, R.; Chew, K.W.; Tan, C.H.; Krishnamoorthy, R.; Chu, D.-T.; Show, P.-L. Waste to bioenergy: A review on the recent conversion technologies. BMC Energy 2019, 1, 1-22. [CrossRef]

2. Rathore, D.; Nizami, A.S.; Singh, A.; Pant, D. Key issues in estimating energy and greenhouse gas savings of biofuels: Challenges and perspectives. Biofuel Res. J. 2016, 3, 380-393. [CrossRef]

3. Sharvini, S.R.; Noor, Z.Z.; Chong, C.S.; Stringer, L.C.; Yusuf, R.O. Energy consumption trends and their linkages with renewable energy policies in East and Southeast Asian countries: Challenges and opportunities. Sustain. Environ. Res. 2018, 28, 257-266. [CrossRef]

4. Ong, H.C.; Chen, W.-H.; Farooq, A.; Gan, Y.Y.; Lee, K.T.; Ashokkumar, V. Catalytic thermochemical conversion of biomass for biofuel production: A comprehensive review. Renew. Sustain. Energy Rev. 2019, 113, 109266. [CrossRef]

5. Ong, Y.K.; Bhatia, S. The current status and perspectives of biofuel production via catalytic cracking of edible and non-edible oils. Energy 2010, 35, 111-119. [CrossRef]

6. Lee, H.; Wu, W.-H.; Chen, B.-H.; Liao, J.-D. Heterogeneous Catalysts Using Strontium Oxide Agglomerates Depositing upon Titanium Plate for Enhancing Biodiesel Production. Catalysts 2021, 11, 30. [CrossRef] 
7. Chownk, M.; Thakur, K.; Purohit, A.; Vashisht, A.; Kumar, S. Applications and Future Perspectives of Synthetic Biology Systems; Elsevier, B.V.: Amsterdam, The Netherlands, 2018; ISBN 9780444640857.

8. Roberts, L.G.; Patterson, T.J. Biofuels. Encycl. Toxicol. Third Ed. 2014, 1, 469-475. [CrossRef]

9. Sindhu, R.; Binod, P.; Pandey, A.; Ankaram, S.; Duan, Y.; Awasthi, M.K. Biofuel Production from Biomass: Toward Sustainable Development; Elsevier B.V.: Amsterdam, The Netherlands, 2019; ISBN 9780444640833.

10. Adav, S.S.; Sze, S.K. Trichoderma Secretome: An Overview; Elsevier: Amsterdam, The Netherlands, $2014 ;$ ISBN 9780444595768.

11. Muhammad, G.; Alam, M.A.; Mofijur, M.; Jahirul, M.I.; Lv, Y.; Xiong, W.; Ong, H.C.; Xu, J. Modern developmental aspects in the field of economical harvesting and biodiesel production from microalgae biomass. Renew. Sustain. Energy Rev. 2021, 135, 110209. [CrossRef]

12. Goh, B.H.H.; Ong, H.C.; Cheah, M.Y.; Chen, W.-H.; Yu, K.L.; Mahlia, T.M.I. Sustainability of direct biodiesel synthesis from microalgae biomass: A critical review. Renew. Sustain. Energy Rev. 2019, 107, 59-74. [CrossRef]

13. Rather, M.A.; Bano, P. Third Generation Biofuels: A Promising Alternate Energy Source. Integr. Green Chem. Sustain. Eng. 2019, 1-21. [CrossRef]

14. Chia, S.R.; Ong, H.C.; Chew, K.W.; Show, P.L.; Phang, S.-M.; Ling, T.C.; Nagarajan, D.; Lee, D.-J.; Chang, J.-S. Sustainable approaches for algae utilisation in bioenergy production. Renew. Energy 2017. [CrossRef]

15. Abdullah, B.; Syed Muhammad, S.A.F.; Shokravi, Z.; Ismail, S.; Kassim, K.A.; Mahmood, A.N.; Aziz, M.M.A. Fourth generation biofuel: A review on risks and mitigation strategies. Renew. Sustain. Energy Rev. 2019, 107, 37-50. [CrossRef]

16. Mat Aron, N.S.; Khoo, K.S.; Chew, K.W.; Show, P.L.; Chen, W.H.; Nguyen, T.H.P. Sustainability of the four generations of biofuels-A review. Int. J. Energy Res. 2020, 44, 9266-9282. [CrossRef]

17. Hassan, M.H.; Kalam, M.A. An overview of biofuel as a renewable energy source: Development and challenges. Procedia Eng. 2013, 56, 39-53. [CrossRef]

18. Faruque, M.O.; Razzak, S.A.; Hossain, M.M. Application of heterogeneous catalysts for biodiesel production from microalgal oil-A review. Catalysts 2020, 10, 1025. [CrossRef]

19. Demirbas, A. Biofuels sources, biofuel policy, biofuel economy and global biofuel projections. Energy Convers. Manag. 2008, 49, 2106-2116. [CrossRef]

20. Reuter Malaysia Palm Oil Output, Exports Forecast to Rise in-MPOB; Thomson Reuters Corporation: Toronto, ON, Canada, 2017.

21. Boey, P.-L.; Maniam, G.P.; Hamid, S.A. Performance of calcium oxide as a heterogeneous catalyst in biodiesel production: A review. Chem. Eng. J. 2011, 168, 15-22. [CrossRef]

22. Luna, C.; Luna, D.; Calero, J.; Bautista, F.M.; Romero, A.A.; Posadillo, A.; Verdugo-Escamilla, C. Biochemical Catalytic Production of Biodiesel; Elsevier Ltd.: Amsterdam, The Netherlands, 2016; Volume 3, ISBN 9780081004562.

23. Basu, P. Production of synthetic fuels and chemicals from biomass. In Biomass Gasification, Pyrolysis Torrefaction. Practical Design and Theory; Elsevier: Amsterdam, The Netherlands, 2018; pp. 415-443.

24. Aydogan, H.; Hirz, M.; Brunner, H. The current use and the future of biofuels. Int. J. Soc. Sci. 2014, 3, $12-21$.

25. Ong, H.C.; Masjuki, H.H.; Mahlia, T.M.I.; Silitonga, A.S.; Chong, W.T.; Leong, K.Y. Optimization of biodiesel production and engine performance from high free fatty acid Calophyllum inophyllum oil in CI diesel engine. Energy Convers. Manag. $2014,81$. [CrossRef]

26. Khuong, L.S.; Zulkifli, N.W.M.; Masjuki, H.H.; Mohamad, E.N.; Arslan, A.; Mosarof, M.H.; Azham, A. A review on the effect of bioethanol dilution on the properties and performance of automotive lubricants in gasoline engines. RSC Adv. 2016, 6, 66847-66869. [CrossRef]

27. Hamza, M.; Ayoub, M.; Shamsuddin, R.B.; Mukhtar, A.; Saqib, S.; Zahid, I.; Ameen, M.; Ullah, S.; Al-sehemi, A.G.; Ibrahim, M. Jou rna 1P. Environ. Technol. Innov. 2020, 101200. [CrossRef]

28. Xue, J.; Grift, T.E.; Hansen, A.C. Effect of biodiesel on engine performances and emissions. Renew. Sustain. Energy Rev. 2011, 15, 1098-1116. [CrossRef]

29. Boro, J.; Deka, D.; Thakur, A.J. A review on solid oxide derived from waste shells as catalyst for biodiesel production. Renew. Sustain. Energy Rev. 2012, 16, 904-910. [CrossRef]

30. Chaveanghong, S.; Smith, S.M.; Smith, C.B.; Luengnaruemitchai, A.; Boonyuen, S. Simultaneous transesterification and esterification of acidic oil feedstocks catalyzed by heterogeneous tungsten loaded bovine bone under mild conditions. Renew. Energy 2018, 126, 156-162. [CrossRef]

31. Bórawski, P.; Bełdycka-Bórawska, A.; Szymańska, E.J.; Jankowski, K.J.; Dubis, B.; Dunn, J.W. Development of renewable energy sources market and biofuels in The European Union. J. Clean. Prod. 2019, 228, 467-484. [CrossRef]

32. Thangarasu, V.; Anand, R. Comparative Evaluation of Corrosion Behavior of Aegle Marmelos Correa Diesel, Biodiesel, and Their Blends on Aluminum and Mild Steel Metals; Elsevier Ltd.: Amsterdam, The Netherlands, 2019; ISBN 9780081027912.

33. Ong, H.C.; Tiong, Y.W.; Goh, B.H.H.; Gan, Y.Y.; Mofijur, M.; Fattah, I.M.R.; Chong, C.T.; Alam, M.A.; Lee, H.V.; Silitonga, A.S.; et al. Recent advances in biodiesel production from agricultural products and microalgae using ionic liquids: Opportunities and challenges. Energy Convers. Manag. 2020, 113647. [CrossRef]

34. Amini, Z.; Ilham, Z.; Ong, H.C.; Mazaheri, H.; Chen, W.-H. State of the art and prospective of lipase-catalyzed transesterification reaction for biodiesel production. Energy Convers. Manag. 2017, 141. [CrossRef]

35. Román-Martínez, M.C.; Salinas-Martínez de Lecea, C. Heterogenization of Homogeneous Catalysts on Carbon Materials; Elsevier, B.V.: Amsterdam, The Netherlands, 2013; ISBN 9780444538765. 
36. Endalew, A.K.; Kiros, Y.; Zanzi, R. Inorganic heterogeneous catalysts for biodiesel production from vegetable oils. Biomass Bioenergy 2011, 35, 3787-3809. [CrossRef]

37. Zabeti, M.; Wan Daud, W.M.A.; Aroua, M.K. Activity of solid catalysts for biodiesel production: A review. Fuel Process. Technol. 2009, 90, 770-777. [CrossRef]

38. Khurshid, S.N.A. Biodiesel Production by Using Heterogeneous Catalysts. Master's Thesis, Royal Institute of Technology (KTH), Stockholm, Sweden, 2014; pp. 1-64.

39. Mat, R.; Samsudin, R.A.; Mohamed, M.; Johari, A. Solid catalysts and their application in biodiesel production. Bull. Chem. React. Eng. Catal. 2012, 7, 142-149. [CrossRef]

40. Lee, H.V.; Juan, J.C.; Taufiq-Yap, Y.H.; Kong, P.S.; Rahman, N.A. Advancement in heterogeneous base catalyzed technology: An efficient production of biodiesel fuels. J. Renew. Sustain. Energy 2015, 7. [CrossRef]

41. Sahu, G.; Gupta, N.K.; Kotha, A.; Saha, S.; Datta, S.; Chavan, P.; Kumari, N.; Dutta, P. A Review on Biodiesel Production through Heterogeneous Catalysis Route. ChemBioEng Rev. 2018, 5, 231-252. [CrossRef]

42. Lee, H.V.; Juan, J.C.; Taufiq-Yap, Y.H. Preparation and application of binary acid-base $\mathrm{CaO}-\mathrm{La}_{2} \mathrm{O}_{3}$ catalyst for biodiesel production Renew. Energy 2015, 74, 124-132. [CrossRef]

43. Taufiq-Yap, Y.H.; Lee, H.V.; Lau, P.L. Transesterification of jatropha curcas oil to biodiesel by using short necked clam (orbicularia orbiculata) shell derived catalyst. Energy Explor. Exploit. 2012, 30. [CrossRef]

44. Xiong, X.; Cai, L.; Jiang, Y.; Han, Q. Eco-efficient, green, and scalable synthesis of 1,2,3-triazoles catalyzed by Cu(I) catalyst on waste oyster shell powders. ACS Sustain. Chem. Eng. 2014, 2, 765-771. [CrossRef]

45. Sheng, X.; Xu, Q.; Wang, X.; Li, N.; Jia, H.; Shi, H.; Niu, M.; Zhang, J.; Ping, Q.W. Waste seashells as a highly active catalyst for cyclopentanone self-aldol condensation. Catalysts 2019, 9, 661. [CrossRef]

46. Mosaddegh, E.; Hassankhani, A. Application and characterization of eggshell as a new biodegradable and heterogeneous catalyst in green synthesis of 7,8-dihydro-4H-chromen-5(6H)-ones. Catal. Commun. 2013, 33, 70-75. [CrossRef]

47. Gao, Y.; Xu, C. Synthesis of dimethyl carbonate over waste eggshell catalyst. Catal. Today 2012, 190, 107-111. [CrossRef]

48. Fan, S.; Yuan, X.; Zhao, L.; Xu, L.H.; Kang, T.J.; Kim, H.T. Experimental and kinetic study of catalytic steam gasification of low rank coal with an environmentally friendly, inexpensive composite $\mathrm{K}_{2} \mathrm{CO}_{3}$-eggshell derived CaO catalyst. Fuel 2016, 165, 397-404. [CrossRef]

49. Luo, H.; Huang, G.; Fu, X.; Liu, X.; Zheng, D.; Peng, J.; Zhang, K.; Huang, B.; Fan, L.; Chen, F.; et al. Waste oyster shell as a kind of active filler to treat the combined wastewater at an estuary. J. Environ. Sci. (China) 2013, 25, 2047-2055. [CrossRef]

50. Bi, D.; Yuan, G.; Wei, J.; Xiao, L.; Feng, L. Conversion of Oyster Shell Waste to Amendment for Immobilising Cadmium and Arsenic in Agricultural Soil. Bull. Environ. Contam. Toxicol. 2020, 105, 277-282. [CrossRef] [PubMed]

51. Pliya, P.; Cree, D. Limestone derived eggshell powder as a replacement in Portland cement mortar. Constr. Build. Mater. 2015, 95, 1-9. [CrossRef]

52. Silva, T.H.; Mesquita-Guimarães, J.; Henriques, B.; Silva, F.S.; Fredel, M.C. The potential use of oyster shell waste in new value-added by-product. Resources 2019, 8, 13. [CrossRef]

53. Huang, Q.; Lu, P.; Hu, B.; Chi, Y.; Yan, J. Cracking of Model Tar Species from the Gasification of Municipal Solid Waste Using Commercial and Waste-Derived Catalysts. Energy Fuels 2016, 30, 5740-5748. [CrossRef]

54. Hart, A. Mini-review of waste shell-derived materials' applications. Waste Manag. Res. 2020, 38, 514-527. [CrossRef] [PubMed]

55. Mazaheri, H.; Ong, H.C.; Masjuki, H.H.; Amini, Z.; Harrison, M.D.; Wang, C.-T.; Kusumo, F.; Alwi, A. Rice bran oil based biodiesel production using calcium oxide catalyst derived from Chicoreus brunneus shell. Energy 2018, 144. [CrossRef]

56. Mansir, N.; Teo, S.H.; Rashid, U.; Saiman, M.I.; Tan, Y.P.; Alsultan, G.A.; Taufiq-Yap, Y.H. Modified waste egg shell derived bifunctional catalyst for biodiesel production from high FFA waste cooking oil. A review. Renew. Sustain. Energy Rev. 2018, 82, 3645-3655. [CrossRef]

57. Morris, J.P.; Backeljau, T.; Chapelle, G. Shells from aquaculture: A valuable biomaterial, not a nuisance waste product. Rev. Aquac. 2019, 11, 42-57. [CrossRef]

58. Guo, F.; Fang, Z. Biodiesel Production with Solid Catalysts. In Biodiesel Feedstocks Processing and Technologies; IntechOpen: London, UK, 2011. [CrossRef]

59. Hattori, H. Solid base catalysts: Fundamentals and their applications in organic reactions. Appl. Catal. A Gen. 2015, 504, 103-109. [CrossRef]

60. Su, M.; Yang, R.; Li, M. Biodiesel production from hempseed oil using alkaline earth metal oxides supporting copper oxide as bi-functional catalysts for transesterification and selective hydrogenation. Fuel 2013, 103, 398-407. [CrossRef]

61. Papargyriou, D.; Broumidis, E.; de Vere-Tucker, M.; Gavrielides, S.; Hilditch, P.; Irvine, J.T.S.; Bonaccorso, A.D. Investigation of solid base catalysts for biodiesel production from fish oil. Renew. Energy 2019, 139, 661-669. [CrossRef]

62. Rizwanul Fattah, I.M.; Ong, H.C.; Mahlia, T.M.I.; Mofijur, M.; Silitonga, A.S.; Rahman, S.M.A.; Ahmad, A. State of the Art of Catalysts for Biodiesel Production. Front. Energy Res. 2020, 8, 1-17. [CrossRef]

63. Roschat, W.; Siritanon, T.; Yoosuk, B.; Promarak, V. Biodiesel production from palm oil using hydrated lime-derived CaO as a low-cost basic heterogeneous catalyst. Energy Convers. Manag. 2016, 108, 459-467. [CrossRef]

64. Latchubugata, C.S.; Kondapaneni, R.V.; Patluri, K.K.; Virendra, U.; Vedantam, S. Kinetics and optimization studies using Response Surface Methodology in biodiesel production using heterogeneous catalyst. Chem. Eng. Res. Des. 2018, 135, 129-139. [CrossRef] 
65. Granados, M.L.; Poves, M.D.Z.; Alonso, D.M.; Mariscal, R.; Galisteo, F.C.; Moreno-Tost, R.; Santamaría, J.; Fierro, J.L.G. Biodiesel from sunflower oil by using activated calcium oxide. Appl. Catal. B Environ. 2007, 73, 317-326. [CrossRef]

66. Liu, X.; He, H.; Wang, Y.; Zhu, S.; Piao, X. Transesterification of soybean oil to biodiesel using CaO as a solid base catalyst. Fuel 2008, 87, 216-221. [CrossRef]

67. Yusuff, A.S.; Adeniyi, O.D.; Olutoye, M.A.; Akpan, U.G. A Review on Application of Heterogeneous Catalyst in the Production of Biodiesel from Vegetable Oils. J. Appl. Sci. Process. Eng. 2017, 4, 142-157. [CrossRef]

68. Food and Agriculture Organization of the United Nation. Globefish Highlights Issue 4 2018; Food and Agriculture Organization of the United Nation: Rome, Italy, 2018; ISBN 9789251312001.

69. Jović, M.; Mandić, M.; Šljivić-Ivanović, M.; Smičiklas, I. Recent trends in application of shell waste from mariculture. Stud. Mar. 2019, 32, 47-62. [CrossRef]

70. FAO. The State of World Fisheries and Aquaculture 2018-Meeting the Sustainable Development Goals; FAO: Rome, Italy, 2018.

71. Viriya-empikul, N.; Krasae, P.; Puttasawat, B.; Yoosuk, B.; Chollacoop, N.; Faungnawakij, K. Waste shells of mollusk and egg as biodiesel production catalysts. Bioresour. Technol. 2010, 101, 3765-3767. [CrossRef]

72. Faridi, H.; Arabhosseini, A. Application of eggshell wastes as valuable and utilizable products: A review. Res. Agric. Eng. 2018, 64, 104-114. [CrossRef]

73. Miyamoto, H.; Miyoshi, F.; Kohno, J. The carbonic anhydrase domain protein nacrein is expressed in the epithelial cells of the mantle and acts as a negative regulator in calcification in the mollusc Pinctada fucata. Zoolog. Sci. 2005, 22, 311-315. [CrossRef] [PubMed]

74. Hangun-Balkir, Y. Green biodiesel synthesis using waste shells as sustainable catalysts with Camelina sativa oil. J. Chem. 2016, 2016. [CrossRef]

75. Chen, B.; Fan, J.; Wang, J.; Peng, X.; Wu, X. Research of nanostructure of bivalva shell. J. Metastable Nanocrystalline Mater. 2005, 23, 83-86. [CrossRef]

76. Abdulrahman, I.; Tijani, H.I.; Mohammed, B.A.; Saidu, H.; Yusuf, H.; Ndejiko Jibrin, M.; Mohammed, S. From Garbage to Biomaterials: An Overview on Egg Shell Based Hydroxyapatite. J. Mater. 2014, 2014, 1-6. [CrossRef]

77. Abdel-Salam, Z.A.; Abdou, A.M.; Harith, M.A. Elemental and ultrastructural analysis of the eggshell: Ca, Mg and Na distribution during embryonic development via LIBS and SEM techniques. Int. J. Poult. Sci. 2006, 5, 35-42. [CrossRef]

78. Hou, Y.; Shavandi, A.; Carne, A.; Bekhit, A.A.; Ng, T.B.; Cheung, R.C.F.; Bekhit, A.E.-d.A. Marine shells: Potential opportunities for extraction of functional and health-promoting materials. Crit. Rev. Environ. Sci. Technol. 2016, 46, 1047-1116. [CrossRef]

79. Chen, X.; Yang, H.; Yan, N. Shell Biorefinery: Dream or Reality? Chem. A Eur. J. 2016, 22, 13402-13421. [CrossRef]

80. Yang, T.; Fu, J.; Ma, L.; Du, H.; Yue, X.; Zhao, B.; Wang, C. Biomimetic synthesis of calcium carbonate under phenylalanine: Control of polymorph and morphology. Mater. Sci. Eng. C 2020, 114, 111019. [CrossRef]

81. Oral, Ç.M.; Ercan, B.; Kapusuz, D. Calcium carbonate polymorph dictates in vitro osteoblast proliferation. J. Aust. Ceram. Soc. 2020. [CrossRef]

82. Barclay, K.M.; Gingras, M.K.; Packer, S.T.; Leighton, L.R. The role of gastropod shell composition and microstructure in resisting dissolution caused by ocean acidification. Mar. Environ. Res. 2020, 162, 105105. [CrossRef]

83. Ramakrishna, C.; Thenepalli, T.; Han, C.; Ahn, J.W. Synthesis of aragonite-precipitated calcium carbonate from oyster shell waste via a carbonation process and its applications. Korean J. Chem. Eng. 2017, 34, 225-230. [CrossRef]

84. Suryawanshi, N.; Jujjavarapu, S.E.; Ayothiraman, S. Marine shell industrial wastes-an abundant source of chitin and its derivatives: Constituents, pretreatment, fermentation, and pleiotropic applications-a revisit. Int. J. Environ. Sci. Technol. 2019, 16, 3877-3898. [CrossRef]

85. Suryaputra, W.; Winata, I.; Indraswati, N.; Ismadji, S. Waste capiz (Amusium cristatum) shell as a new heterogeneous catalyst for biodiesel production. Renew. Energy 2013, 50, 795-799. [CrossRef]

86. Buasri, A.; Chaiyut, N.; Loryuenyong, V.; Worawanitchaphong, P.; Trongyong, S. Calcium oxide derived from waste shells of mussel, cockle, and scallop as the heterogeneous catalyst for biodiesel production. Sci. World J. 2013, 2013. [CrossRef] [PubMed]

87. Khemthong, P.; Luadthong, C.; Nualpaeng, W.; Changsuwan, P.; Tongprem, P.; Viriya-Empikul, N.; Faungnawakij, K. Industrial eggshell wastes as the heterogeneous catalysts for microwave-assisted biodiesel production. Catal. Today 2012, 190, 112-116. [CrossRef]

88. Aitlaalim, A.; Ouanji, F.; Benzaouak, A.; El Mahi, M.; Lotfi, E.M.; Kacimi, M.; Liotta, L.F. Utilization of waste grooved razor shell (Grs) as a catalyst in biodiesel production from refined and waste cooking oils. Catalysts 2020, 10, 703. [CrossRef]

89. Jairam, S.; Kolar, P.; Sharma-Shivappa Ratna, R.; Osborne, J.A.; Davis, J.P. KI-impregnated oyster shell as a solid catalyst for soybean oil transesterification. Bioresour. Technol. 2012, 104, 329-335. [CrossRef]

90. Lin, Y.C.; Amesho, K.T.T.; Chen, C.E.; Cheng, P.C.; Chou, F.C. A cleaner process for green biodiesel synthesis from waste cooking oil using recycled waste oyster shells as a sustainable base heterogeneous catalyst under the microwave heating system. Sustain. Chem. Pharm. 2020, 17, 100310. [CrossRef]

91. Sirisomboonchai, S.; Abuduwayiti, M.; Guan, G.; Samart, C.; Abliz, S.; Hao, X.; Kusakabe, K.; Abudula, A. Biodiesel production from waste cooking oil using calcined scallop shell as catalyst. Energy Convers. Manag. 2015, 95, 242-247. [CrossRef]

92. Laskar, I.B.; Rajkumari, K.; Gupta, R.; Chatterjee, S.; Paul, B.; Rokhum, L. Waste snail shell derived heterogeneous catalyst for biodiesel production by the transesterification of soybean oil. RSC Adv. 2018, 8, 20131-20142. [CrossRef] 
93. Buasri, A.; Loryuenyong, V. Application of waste materials as a heterogeneous catalyst for biodiesel production from Jatropha Curcas oil via microwave irradiation. Mater. Today Proc. 2017, 4, 6051-6059. [CrossRef]

94. Colombo, K.; Ender, L.; Barros, A.A.C. The study of biodiesel production using CaO as a heterogeneous catalytic reaction. Egypt J. Pet. 2017, 26, 341-349. [CrossRef]

95. Milano, J.; Ong, H.C.; Masjuki, H.H.; Silitonga, A.S.; Chen, W.H.; Kusumo, F.; Dharma, S.; Sebayang, A.H. Optimization of biodiesel production by microwave irradiation-assisted transesterification for waste cooking oil-Calophyllum inophyllum oil via response surface methodology. Energy Convers. Manag. 2018, 158, 400-415. [CrossRef]

96. Zhang, H.; Wang, Q.; Mortimer, S.R. Waste cooking oil as an energy resource: Review of Chinese policies. Renew. Sustain. Energy Rev. 2012, 16, 5225-5231. [CrossRef]

97. Oldham, D.; Rajib, A.; Dandamudi, K.P.R.; Liu, Y.; Deng, S.; Fini, E.H. Transesterification of Waste Cooking Oil to Produce A Sustainable Rejuvenator for Aged Asphalt. Resour. Conserv. Recycl. 2020, 105297. [CrossRef]

98. Gaur, A.; Mishra, S.; Chowdhury, S.; Baredar, P.; Verma, P. A review on factor affecting biodiesel production from waste cooking oil: An Indian perspective. Mater. Today Proc. 2020. [CrossRef]

99. Elias, S.; Rabiu, A.M.; Okeleye, B.I.; Okudoh, V.; Oyekola, O. Bifunctional heterogeneous catalyst for biodiesel production from waste vegetable oil. Appl. Sci. 2020, 10, 3153. [CrossRef]

100. Asikin-Mijan, N.; Lee, H.V.; Taufiq-Yap, Y.H. Synthesis and catalytic activity of hydration-dehydration treated clamshell derived $\mathrm{CaO}$ for biodiesel production. Chem. Eng. Res. Des. 2015, 102, 368-377. [CrossRef]

101. Védrine, J.C. Acid-base characterization of heterogeneous catalysts: An up-to-date overview. Res. Chem. Intermed. 2015, 41, 9387-9423. [CrossRef]

102. Endalew, A.K.; Kiros, Y.; Zanzi, R. Heterogeneous catalysis for biodiesel production from Jatropha curcas oil (JCO). Energy 2011, 36, 2693-2700. [CrossRef]

103. Tomano, N.; Prokaew, A.; Boonyuen, S.; Ummartyotin, S. Development of Sr/Cao catalyst derived from cuttlebone (Sepia officinalis) for biodiesel production. J. Met. Mater. Miner. 2020, 30, 40-47. [CrossRef]

104. Boro, J.; Konwar, L.J.; Thakur, A.J.; Deka, D. Ba doped CaO derived from waste shells of T striatula (TS-CaO) as heterogeneous catalyst for biodiesel production. Fuel 2014, 129, 182-187. [CrossRef]

105. Foroutan, R.; Mohammadi, R.; Esmaeili, H.; Mirzaee Bektashi, F.; Tamjidi, S. Transesterification of waste edible oils to biodiesel using calcium oxide@magnesium oxide nanocatalyst. Waste Manag. 2020, 105, 373-383. [CrossRef] [PubMed]

106. Boro, J.; Konwar, L.J.; Deka, D. Transesterification of non edible feedstock with lithium incorporated egg shell derived CaO for biodiesel production. Fuel Process. Technol. 2014, 122, 72-78. [CrossRef]

107. He, Z.; Wang, X. Renewable energy and fuel production over transition metal oxides: The role of oxygen defects and acidity. Catal. Today 2014, 240, 220-228. [CrossRef]

108. Lee, H.V.; Juan, J.C.; Binti Abdullah, N.F.; Nizah Mf, R.; Taufiq-Yap, Y.H. Heterogeneous base catalysts for edible palm and non-edible Jatropha-based biodiesel production. Chem. Cent. J. 2014, 8, 30. [CrossRef]

109. Joshi, G.; Rawat, D.S.; Lamba, B.Y.; Bisht, K.K.; Kumar, P.; Kumar, N.; Kumar, S. Transesterification of Jatropha and Karanja oils by using waste egg shell derived calcium based mixed metal oxides. Energy Convers. Manag. 2015, 96, 258-267. [CrossRef]

110. Rahman, W.U.; Fatima, A.; Anwer, A.H.; Athar, M.; Khan, M.Z.; Khan, N.A.; Halder, G. Biodiesel synthesis from eucalyptus oil by utilizing waste egg shell derived calcium based metal oxide catalyst. Process. Saf. Environ. Prot. 2019, 122, 313-319. [CrossRef]

111. Kaur, N.; Ali, A. Biodiesel production via ethanolysis of jatropha oil using molybdenum impregnated calcium oxide as solid catalyst. RSC Adv. 2015, 5, 13285-13295. [CrossRef]

112. Das, V.; Tripathi, A.M.; Borah, M.J.; Dunford, N.T.; Deka, D. Cobalt-doped CaO catalyst synthesized and applied for algal biodiesel production. Renew. Energy 2020, 161, 1110-1119. [CrossRef]

113. Mansir, N.; Hwa Teo, S.; Lokman Ibrahim, M.; Yun Hin, T.Y. Synthesis and application of waste egg shell derived CaO supported W-Mo mixed oxide catalysts for FAME production from waste cooking oil: Effect of stoichiometry. Energy Convers. Manag. 2017, 151, 216-226. [CrossRef]

114. Borah, M.J.; Das, A.; Das, V.; Bhuyan, N.; Deka, D. Transesterification of waste cooking oil for biodiesel production catalyzed by Zn substituted waste egg shell derived CaO nanocatalyst. Fuel 2019, 242, 345-354. [CrossRef]

115. Helwani, Z.; Ramli, M.; Saputra, E.; Bahruddin, B.; Yolanda, D.; Fatra, W.; Idroes, G.M.; Muslem, M.; Mahlia, T.M.I.; Idroes, R. Impregnation of $\mathrm{CaO}$ from eggshell waste with magnetite as a solid catalyst $\left(\mathrm{Fe}_{3} \mathrm{O}_{4} / \mathrm{CaO}\right)$ for transesterification of palm oil off-grade. Catalysts 2020, 10, 164. [CrossRef]

116. Dorozhkin, S.V. Functionalized calcium orthophosphates $\left(\mathrm{CaPO}_{4}\right)$ and their biomedical applications. J. Mater. Chem. B 2019, 7 , 7471-7489. [CrossRef] [PubMed]

117. Hawa, K.A.; Helwani, Z.; Amri, A. Synthesis of Heterogeneous Catalysts NaOH/CaO/C From Eggshells for Biodiesel Production Using Off-Grade Palm Oil. J. Rekayasa Kim. Lingkung. 2020, 15, 31-37. [CrossRef]

118. Nurhayati; Amri, T.A.; Annisa, N.F.; Syafitri, F. The Synthesis of Biodiesel from Crude Palm Oil (CPO) using CaO Heterogeneous Catalyst Impregnated $\mathrm{H}_{2} \mathrm{SO}_{4}$,Variation of Stirring Speed and Mole Ratio of Oil to Methanol. J. Phys. Conf. Ser. $2020,1655$. [CrossRef]

119. Cho, Y.B.; Seo, G. High activity of acid-treated quail eggshell catalysts in the transesterification of palm oil with methanol. Bioresour. Technol. 2010, 101, 8515-8519. [CrossRef] 
120. Nur Syazwani, O.; Rashid, U.; Taufiq Yap, Y.H. Low-cost solid catalyst derived from waste Cyrtopleura costata (Angel Wing Shell) for biodiesel production using microalgae oil. Energy Convers. Manag. 2015, 101, 749-756. [CrossRef]

121. Syazwani, O.N.; Rashid, U.; Mastuli, M.S.; Taufiq-Yap, Y.H. Esterification of palm fatty acid distillate (PFAD) to biodiesel using Bi-functional catalyst synthesized from waste angel wing shell (Cyrtopleura costata). Renew. Energy 2019, 131, 187-196. [CrossRef]

122. Nurdin, S.; Rosnan, N.A.; Ghazali, N.S.; Gimbun, J.; Nour, A.H.; Haron, S.F. Economical Biodiesel Fuel Synthesis from Castor Oil Using Mussel Shell-Base Catalyst (MS-BC); Elsevier B.V.: Amsterdam, The Netherlands, 2015; Volume 79.

123. Thi, T.; Myat, M. Synthesis and Characterization of $\mathrm{CaO}$ and KF Doped $\mathrm{CaO}(\mathrm{KF} / \mathrm{CaO})$ Derived from Chicken Eggshell Waste as Heterogeneous Catalyst in Biodiesel Production. Am. Sci. Res. J. Eng. Technol. Sci. 2017, 38, 134-151.

124. Komintarachat, C.; Chuepeng, S. Catalytic enhancement of calcium oxide from green mussel shell by potassium chloride impregnation for waste cooking oil-based biodiesel production. Bioresour. Technol. Reports 2020, 100589. [CrossRef]

125. Yoosuk, B.; Udomsap, P.; Puttasawat, B.; Krasae, P. Modification of calcite by hydration-dehydration method for heterogeneous biodiesel production process: The effects of water on properties and activity. Chem. Eng. J. 2010, 162, 135-141. [CrossRef]

126. Ahmad, S.; Chaudhary, S.; Pathak, V.V.; Kothari, R.; Tyagi, V.V. Optimization of direct transesterification of Chlorella pyrenoidosa catalyzed by waste egg shell based heterogenous nano-CaO catalyst. Renew. Energy 2020, 160, 86-97. [CrossRef]

127. Niju, S.; Meera Sheriffa Begum, K.M.; Anantharaman, N. Enhancement of biodiesel synthesis over highly active CaO derived from natural white bivalve clam shell Enhancement of biodiesel synthesis over highly active CaO. Arab. J. Chem. 2016, 9, 633-639. [CrossRef]

128. Niju, S.; Indhumathi, J.; Begum, K.M.M.S.; Anantharaman, N. Tellina tenuis: A highly active environmentally benign catalyst for the transesterification process. Biofuels 2017, 8, 565-570. [CrossRef]

129. Niju, S.; Rabia, R.; Sumithra Devi, K.; Naveen Kumar, M.; Balajii, M. Modified Malleus malleus Shells for Biodiesel Production from Waste Cooking Oil: An Optimization Study Using Box-Behnken Design. Waste Biomass Valorization 2020, 11, 793-806. [CrossRef]

130. Chen, G.Y.; Shan, R.; Yan, B.B.; Shi, J.F.; Li, S.Y.; Liu, C.Y. Remarkably enhancing the biodiesel yield from palm oil upon abalone shell-derived $\mathrm{CaO}$ catalysts treated by ethanol. Fuel Process. Technol. 2016, 143, 110-117. [CrossRef]

131. Marinković, D.M.; Stanković, M.V.; Veličković, A.V.; Avramović, J.M.; Miladinović, M.R.; Stamenković, O.O.; Veljković, V.B.; Jovanović, D.M. Calcium oxide as a promising heterogeneous catalyst for biodiesel production: Current state and perspectives. Renew. Sustain. Energy Rev. 2016, 56, 1387-1408. [CrossRef]

132. Irvine, W.M. Eley-Rideal Mechanism. In Encyclopedia of Astrobiology; Gargaud, M., Amils, R., Quintanilla, J.C., Cleaves, H.J., Irvine, W.M., Pinti, D.L., Viso, M., Eds.; Springer: Berlin/Heidelberg, Germany, 2011; p. 485. ISBN 978-3-642-11274-4.

133. Al-Sakkari, E.G.; El-Sheltawy, S.T.; Attia, N.K.; Mostafa, S.R. Kinetic study of soybean oil methanolysis using cement kiln dust as a heterogeneous catalyst for biodiesel production. Appl. Catal. B Environ. 2017, 206, 146-157. [CrossRef]

134. Widiarti, N.; Ni'mah, Y.L.; Bahruji, H.; Prasetyoko, D. Development of CaO from natural calcite as a heterogeneous base catalyst in the formation of biodiesel: Review. J. Renew. Mater. 2019, 7, 915-939. [CrossRef]

135. Kouzu, M.; Hidaka, J. Transesterification of vegetable oil into biodiesel catalyzed by CaO: A review. Fuel 2012, 93, 1-12. [CrossRef]

136. Kesic, Z.; Lukic, I.; Zdujic, M.; Mojovic, L.; Skala, D. Calcium oxide based catalysts for biodiesel production: A review. Chem. Ind. Chem. Eng. Q. 2016, 22, 391-408. [CrossRef]

137. Pasupulety, N.; Gunda, K.; Liu, Y.; Rempel, G.L.; Ng, F.T.T. Production of biodiesel from soybean oil on $\mathrm{CaO} / \mathrm{Al}_{2} \mathrm{O}_{3}$ solid base catalysts. Appl. Catal. A Gen. 2013, 452, 189-202. [CrossRef]

138. Tshizanga, N.; Aransiola, E.F.; Oyekola, O. Optimisation of biodiesel production from waste vegetable oil and eggshell ash. S. Afr. J. Chem. Eng. 2017, 23, 145-156. [CrossRef]

139. Niju, S.; Begum, M.M.M.S.; Anantharaman, N. Modification of egg shell and its application in biodiesel production. J. Saudi Chem. Soc. 2014, 18, 702-706. [CrossRef]

140. Shinde, K.; Kaliaguine, S. A comparative study of ultrasound biodiesel production using different homogeneous catalysts. ChemEngineering 2019, 3, 18. [CrossRef]

141. Changmai, B.; Vanlalveni, C.; Ingle, P. Widely used catalysts in biodiesel production: A review. RSC Adv. 2020, 41625-41679. [CrossRef]

142. Teixeira, L.S.G.; Assis, J.C.R.; Mendonça, D.R.; Santos, I.T.V.; Guimarães, P.R.B.; Pontes, L.A.M.; Teixeira, J.S.R. Comparison between conventional and ultrasonic preparation of beef tallow biodiesel. Fuel Process. Technol. 2009, 90, 1164-1166. [CrossRef]

143. Tan, S.X.; Lim, S.; Ong, H.C.; Pang, Y.L. State of the art review on development of ultrasound-assisted catalytic transesterification process for biodiesel production. Fuel 2019, 235, 886-907. [CrossRef]

144. Widayat, W.; Darmawan, T.; Rosyid, R.A.; Hadiyanto, H. Biodiesel Production by Using CaO Catalyst and Ultrasonic Assisted. J. Phys. Conf. Ser. 2017, 877. [CrossRef]

145. Mootabadi, H.; Salamatinia, B.; Bhatia, S.; Abdullah, A.Z. Ultrasonic-assisted biodiesel production process from palm oil using alkaline earth metal oxides as the heterogeneous catalysts. Fuel 2010, 89, 1818-1825. [CrossRef]

146. Chen, G.; Shan, R.; Shi, J.; Yan, B. Ultrasonic-assisted production of biodiesel from transesterification of palm oil over ostrich eggshell-derived $\mathrm{CaO}$ catalysts. Bioresour. Technol. 2014, 171, 428-432. [CrossRef] [PubMed]

147. Jaliliannosrati, H.; Amin, N.A.S.; Talebian-Kiakalaieh, A.; Noshadi, I. Microwave assisted biodiesel production from Jatropha curcas L. seed by two-step in situ process: Optimization using response surface methodology. Bioresour. Technol. 2013, 136, 565-573. [CrossRef] [PubMed] 
148. Kant Bhatia, S.; Kant Bhatia, R.; Jeon, J.M.; Pugazhendhi, A.; Kumar Awasthi, M.; Kumar, D.; Kumar, G.; Yoon, J.J.; Yang, Y.H. An overview on advancements in biobased transesterification methods for biodiesel production: Oil resources, extraction, biocatalysts, and process intensification technologies. Fuel 2021, 285, 119117. [CrossRef]

149. Geuens, J.; Kremsner, J.M.; Nebel, B.A.; Schober, S.; Dommisse, R.A.; Mittelbach, M.; Tavernier, S.; Kappe, C.O.; Maes, B.U.W. Microwave-assisted catalyst-free transesterification of triglycerides with 1-butanol under supercritical conditions. Energy Fuels 2008, 22, 643-645. [CrossRef]

150. Zhang, S.; Zu, Y.G.; Fu, Y.J.; Luo, M.; Zhang, D.Y.; Efferth, T. Rapid microwave-assisted transesterification of yellow horn oil to biodiesel using a heteropolyacid solid catalyst. Bioresour. Technol. 2010, 101, 931-936. [CrossRef]

151. Liao, C.C.; Chung, T.W. Optimization of process conditions using response surface methodology for the microwave-assisted transesterification of Jatropha oil with KOH impregnated CaO as catalyst. Chem. Eng. Res. Des. 2013, 91, 2457-2464. [CrossRef]

152. Zamberi, M.M.; Ani, F.N.; Abdollah, M.F. The application of calcium oxide from waste cockle for biodiesel production from used cooking oil via microwave heating system. J. Adv. Res. Fluid Mech. Therm. Sci. 2018, 49, 92-100.

153. Peng, Y.P.; Amesho, K.T.T.; Chen, C.E.; Jhang, S.R.; Chou, F.C.; Lin, Y.C. Optimization of biodiesel production from waste cooking oil using waste eggshell as a base catalyst under a microwave heating system. Catalysts 2018, 8, 81. [CrossRef]

154. Shan, R.; Zhao, C.; Lv, P.; Yuan, H.; Yao, J. Catalytic applications of calcium rich waste materials for biodiesel: Current state and perspectives. Energy Convers. Manag. 2016, 127, 273-283. [CrossRef]

155. Weissman, A.M.; Yang, Y.; Kitagaki, J.; Sasiela, C.A.; Beutler, J.A. Scale-Up in Microwave-Accelerated Organic Synthesis. Cancer 2007, 3, 133-149. [CrossRef]

156. Almasi, S.; Ghobadian, B.; Najafi, G.H.; Yusaf, T.; Soufi, M.D.; Hoseini, S.S. Optimization of an ultrasonic-assisted biodiesel production process from one genotype of rapeseed (Teri (OE) R-983) as a novel feedstock using response surface methodology. Energies 2019, 12, 2656. [CrossRef] 